\title{
Literatürde Olmayan Bir Tabloda Ming Halısı ve Ming Halıları
}

Dr. Öğr. Üyesi Servet Senem UĞURLU Mimar Sinan Güzel Sanatlar Üniversitesi GSF, Geleneksel Türk Sanatları Bölümü senem-ugurlu@windowslive.com ORCID: 0000-0003-2307-9623

\begin{abstract}
Öz
14.-15. yüzyıllarda Anadolu'da dokunmuş hayvan motifli halılar, birçok araştırmacının dikkatini çekmektedir. Bu dönemde Anadolu'da farklı motifler ve desen kompozisyonlarında oluşturulmuş halılar dokunmuştur. Halı ortalarındaki desen kompozisyonları; kare, eşkenar dörtgen, sekizgen, üçgen gibi belirli geometrik şekillerle oluşturulmuştur. Bölümler içinde stilize edilmiş sembolik halde mitolojik değerler taşıyan hayvan motifleri kullanılmıştır. Dört yöne ihraç edildiği bilinen hayvan motifli Anadolu halıları, Batı sanatında ve öncelikle italyan ressamların tablolarında 14. yüzyıl başından itibaren görülmektedir. Bu halılar özellikle Sienalı ve Floransalı ressamların tablolarında resimlenmiştir. 14. yüzyıl sonu-15. yüzyıl Anadolu halıları arasında öne çıkan önemli, ünlü ve karakteristik özellikler içeren halılar vardır. En ünlüsü Wilhelm von Bode tarafından Berlin İslam Eserleri Müzesi'ne satın alınan Ejderha ve Anka kuşu motifli halı'dır. Bu halı, Anadolu Beylikleri Dönemi hayvan motifli halıları içinde en iyi korunmuş tek örnektir. 1905 yllında Martin'in Konya'daki Alaeddin Camisinde 13. yüzyıl Selçuklu hallıarını keşfine kadar, Ming halısı dünyanın en eski halısı olarak tanıtılmıştır. Kurt Erdmann, Batılı ressamların tablolarındaki halı tasvirlerinden yararlanarak hallıarın tarihlerinin belirleneceğini öne sürmüş, Wilhelm von Bode İtalya'dan satın aldığı Ming halısının tarihini bu yöntemle bulmuştur. Bu halı, ilk önce Bode halısı, daha sonrasında ise Ming halısı olarak isimlendirilmiştir. Bu araştırmada, Ming halısı yeni bilgilerle incelenerek tipolojik ve ikonografik olarak açıklanacaktır.
\end{abstract}

Anahtar Kelimeler: ming halısı, ejderha, anka kuşu, tasarım, halı, tablo

Uğurlu, S. (2021). Literatürde Olmayan Bir Tabloda Ming Halısı ve Ming Halıları. ARTS: Artuklu Sanat ve Beşeri Bilimler Dergisi, 6, 329-357. 


\title{
arts $=$
}

\section{The Ming Carpet on the An Unmentioned Painting in Turkish Carpets and Ming Carpets}

\begin{abstract}
In the 14th-15th centuries carpets with animal motifs woven in Anatolia attract the attention of many researchers. In this period, carpets created with different motifs and pattern compositions were woven in Anatolia. Pattern compositions in the middle of the carpet; It was created with certain geometric shapes such as square, rhombus, octagon, triangle. Animal motifs with mythological values in stylized symbolic form were used within the sections. Anatolian carpets with animal motifs, known to be exported in four directions, have been seen in Western art and primarily in the paintings of Italian painters since the beginning of the 14 th century. These carpets are especially portraited in the paintings of Siena and Florentine painters. Among at the end of 14th century - the beginning of 15th the Anatolian carpets, there are carpets with important, famous and characteristic features. The most famous is the dragon and phoenix motif carpet purchased by Wilhelm von Bode to the Berlin Museum of Islamic Art. This carpet is the best-preserved example among the animal motif carpets of the Anatolian Principalities Period. The Ming carpet was promoted as the world's oldest carpet until 1905 when Martin discovered 13th century Seljuk carpets at the Alaeddin Mosque in Konya. Kurt Erdmann claimed that the dates of the carpets would be determined by using the carpet depictions in the paintings of Western painters, and Wilhelm von Bode found the date of the Ming carpet she bought from Italy with this method. This carpet was first named as Bode carpet and later as Ming carpet. In this research, the Ming carpet will be examined with new information and explained typologically and iconographically.
\end{abstract}

Keywords: ming carpet, dragon, phoenix, design, carpet, painting 


\section{arts}

\section{Gíriş}

Türk halıları hakkında yapılan araştırmalarla her geçen gün konuyla ilgili bilgi ve örnekler artmaktadır. "Bu çalışmalar bugün bazı sahalarda öylesine ilerledi ki artık halıların gelişmesini ana hatlarıyla görebilecek haldeyiz. Ama yine de bazı meseleler cevapsız kalmış bulunuyor. Bilhassa Türk halıları bahsinde bilmediğimiz pek çok şeyler vardır" (Erdmann, , s. 83).

Türk Halıcılığı hakkında ilk araştırmalar, 19. yüzyılın son çeyreğinde, Batı Avrupalı ve Kuzey Amerikalı araştırmacılar tarafından Doğu halıları ve halıcılık hakkında bilimsel araştırmalar ile başlamıştır. Bu sürecin sonunda toplanan ve satın alınan halılar, tasnif edilerek belgelenmişlerdir. Batılı araştırmacıların dikkatini önceleri İran halıları çekmiş ve bu halı desenlerinin İran minyatürleri etkisinde olduğunu fark etmişlerdir. Kurt Erdmann, İran ve Türk halılarını karşılaştırdığında, Türk halılarının gelişmesinin daha istikrarlı olduğunu belirtmiştir (Erdmann, _, s. 83-84-85). Batılı araştırmacılar, Anadolu' daki Yörük ve Türkmenlerin minimalist yaşamda dokudukları halıları gördükten sonra, Anadolu halılarının sanatsal açıdan özgün olduklarını görmüş ve araştırmalarını Anadolu'ya yönlendirmişlerdir.

14.-15. yüzyllarda Anadolu'da dokunmuş hallıarda temel olarak hayvan motifleri kullanılmıştır. Türk halıclığının önemli bir grubunu oluşturan hayvan motifli halıların farklı örnekleri, dünyada çeşitli müze ve özel koleksiyonlarda bulunmaktadır. Fustat (Eski Kahire) ve Doğu Türkistan'da Lop Gölü batısındaki Lou-Lan'da bulunan halı parçaları örnekleri ile hayvan motifli halı grubunun örnek sayısı artmıştır (Aslanapa, 2005, s. 19-24).

Araştırmanın amacl; Ming halısının resmedildiği bir tablo, Ming halısı ve çeşitli örnekleri ile bu halının motif- desen özelliklerini içermektedir. Ming halısı ile bağlantıı iki tablo incelenecek ve literatürde olmayan Ming halısıyla ilgili bir tablo hakkında bilgi verilecektir. 14.-15. yüzyıl hayvan motifli Anadolu halıları hakkında verilen bilgiler doğrultusunda, Ming halısının tipolojik ve ikonografik bağlantıları incelenecektir. Ayrıca Berlin İslam Sanatları Müzesi koleksiyonundaki Ming halısı örneğinin yanı sıra Fustat'ta bulunmuş halı parçası ile Berlin ve Basel'de korunan toplam üç farklı Ming halısı parçalarından bahsedilecektir. Ming halısının desen kompozisyonları ile motiflerin desen kompozisyonundaki dağlımı el çizimleri yapılacak ve olası desen kompozisyon sistemi çeşitliliği hakkında bilgi verilecektir.

Araştırma kapsamı; ulaşılabilen yerli ve yabancı kaynaklardaki bilgiler ile 
öncelikle literatürde olmayan Ming halısının resmedildiği bir tablo, Berlin İslam Sanatları Müzesi koleksiyonundaki 14. yüzyıl Ejder ve Anka kuşu motifli Anadolu halısı ile dünyada farklı koleksiyonlarda bulunan üç farklı Ming halısı parçalarını içermektedir.

Araştırmada, nitel araştırma türlerinden ilişkisel araştırma yöntemi kullanılmıştır. Ming halısı ve Ming halısının resmedildiği tablolar araştırımış, halı ve literatürde olmayan bir tablo arasına ilişki araştırımıştır. Berlin İslam Sanatları Müzesi koleksiyonunda çekilen görsellerinden yararlanılarak Ming halısının restitüsyonu yapılmış, günümüze eksik parça olarak ulaşmış halının tasarım önerisi sunulmuştur.

\section{BULGULAR VE TARTIŞMA}

Bu araştırma konusu kapsamında Ming halısının resmedildiği bilinen tabloların yanı sıra literatürde olmayan bir tablo tespit edilmiştir. Berlin İslam Sanatları Müzesi koleksiyonunda korunan Ming halısına ek olarak farklı müze ve koleksiyonlarda bulunan üç adet Ming halısı parçası hakkında araştırma yapılarak incelenmiştir. Günümüze ulaşan tablolarında Ming halılarını resmeden Batılı ressamların İtalyanlar olduğu görülmüştür. Ming halısının ilk olarak Roma' da bir antikacıda Wilhelm von Bode tarafından keşfedildiği, motif ve desen kompozisyonunu ilginç bulduğundan Berlin İslam Sanatları Müzesi koleksiyonuna dahil edilmesi için satın aldığı bilinmektedir. Ming halılarında Ejderha ve Anka kuşunun savaşı betimlenmiştir. Halıların orta zeminlerinin renginin daima sarı renkte olduğu görülmüştür. Halı motiflerinde kullanılan renkler ise özellikle kırmızı, koyu mavi /lacivert, beyaz, siyah gibi renklerdir.

Bu araştırma, literatürde olmayan Ming halısının resmedildiği bir tablonun incelenmesi ve literatüre kazandırıması için yapılmıştır. Araştırma, eski ve yeni bilgilerin bir araya getirilmesiyle oluşturulmuş ve hayvan motifli halılar ile Ming halısı hakkında yeni bilgilere yönelik çalışıımıştır.

\section{4.-15. Yüzyılda Anadolu'da Tarihsel Süreç}

Anadolu Selçukluları döneminde Alaaddin Keykubat, 1220 yllında Venedikliler ile anlaşma yapmış ve onlara yasal özerklikler tanımıştır. 1255 yılında Venediklilerin İskenderiye ve Antalya arasında bağ kurmaları sonucunda Antalya limanı kurulmuştur (Cahen, 1994, s. 169). 13. yüzyılın ilk çeyreğinde Türkistan ve İran'ı istila eden Moğollar, kısa süre içerisinde Anadolu Selçukluları için doğudan 


\section{arts}

gelen bir tehlike olmuştur. 1243'te Kösedağ Savaşı ile Moğollar tarafından bozguna uğrayan Anadolu Selçukluları, savaş sonrasında sosyal, siyasal ve ekonomik kaynakları sömürülen bir ülke haline gelmiştir (Ersan ve Alican, 2014, s. 16). Anadolu Selçuklu toprakları, Moğol valiler tarafından 13. yüzyılın sonuna kadar yönetilmiştir. Bu dönemde Moğollar Anadolu'da mevcut olmalarına karşın neredeyse görünmez haldedir (Faroghi, 2018, s. 83). Anadolu'daki Moğol egemenliğinin son döneminde, Anadolu Türk Beylikleri kurulmaya başlamıştır.

Anadolu Beylikleri, Anadolu'nun her tarafında bağımsız ya da yarı bağımsız güçlü duruşları ile dikkat çekmiş ve Anadolu'yu sosyal, siyasal, ekonomik, mimari yönlerden kalkındırmışlardır (Werner, 2014, s. 80). Bunların başında ise Oğuz boylarından olan Yörük ve Türkmenlerin dokudukları halı ve kilimler önemli bir yer tutmaktadır. Marco Polo, Anadolu Türkmenleri tarafından dokunan Selçuklu halılarını dikkat çekici değerde bularak bahsetmiştir (Schmidt, 1958, s. 74-75). Anadolu Selçukluları, Türkmen beylerinin yüksek güç ve gayretleri ile kalkınmış ve 14. yüzyılda yetmiş-seksen sene kadar bir refah oluşmuştur (Uzunçarşılı, 1988, s. 256). Moğolların Anadolu Beylikleri ile arası oldukça iyi olmuştur. Ayrıca bu dönemde Anadolu Beylikleri toplumunda hoşgörü ve düzenin arttığı görülmektedir. Anadolu Selçuklularının özellikle önem verdiği yabancılarla ticaret bağlantıları, Anadolu Beylikleri döneminde de artarak devam etmiş, Anadolu'dan yurtdışına ihraç edilen halı ve kilim gibi dokumalar Anadolu Beylikleri döneminde de önemini korumuştur. Bu dönemin Anadolu halıları prestij ve zenginlik göstergesi nadir eserler olarak kabul edildiği için, "Avrupa' da 'deniz aşırı halılar' diye anılmış, değerlerini belirlemede başka bir mahreç isim aranmamıştı"" (Uzunçarşılı, 1988, s. 252). 14. yüzyıl sonundan 15. yüzyıl başına kadar olan süreçte, veba salgını nedeniyle Anadolu'daki nüfusun azaldığı bilinmektedir (Faroqhi, 2018, s. 69). Büyük intimalle bu dönemde Anadolu'da halı ticareti yavaşladığı için sınırlı sayıda halı ihracatı yapılmış olduğu düşünülmektedir.

Bu dönemde Anadolu ile ticari ilişkileri olan Avrupalılar; Venedik, Ceneviz, Floransa, Napoli ve Anju hükümetleridir (Uzunçarşıll, 1988, s. 254). Özellikle Floransa, Napoli ve Anju hükümetlerinin Saruhanoğulları, Aydınoğulları ve Menteşeoğulları ile ticaret bağlantıları vardır. Bu nedenle bu devletlerin Bursa'da ve ticaret yaptıkları Batı Anadolu Beyliklerinin şehirlerinde eşya depolarının olduğu bilinmektedir (Uzunçarşılı, 1988, s. 255). Anadolu Selçukluları döneminde Venedikliler, genellikle Karamanoğulları ve Menteşeoğulları Beylikleri ile Akdeniz ve Ege sahillerinden ticareł yapmıştır (Uzunçarşılı, 1988, s. 254). Bu bölgelerde İran'daki Moğol hanedanı olan 
İlhanlılar ile Kuzeybałı Anadolu'da ise Osmanlı Beyliği yerel güç haline gelmişlerdir (Ersan ve Alican, 2014, s. 16).

\section{Hayvan Motifil Halılar}

Türk Halıcılığında, Anadolu'da 13. yüzyıl Anadolu Selçuklu halılarından sonra 14.-15. yüzyllarda hayvan motifli halılar dokunmuştur. Orta Asya bozkır kültürü ile Anadolu'ya gelen Yörük ve Türkmenler, göçebe yaşamlarında geçimlerini hayvancılıkla sağladıkları için doğadaki hayvanlara yabancı değillerdi. Halı ve öykülerinde gerçeküstü varlıklar ile doğada gördükleri hayvanları bir arada motif olarak görselleştirmişlerdir. Ayrıca bu dönemde Moğol saldıılarından kaçan Oğuz boylarının İran ve Kafkasya üzerinden Anadolu'ya göçleri devam etmiştir. Tüm bu göçlerin üzerine ek olarak Timur yönetimindeki Moğollar da işgal etmek için Anadolu'ya gelmişlerdir. Sonuç olarak, bu hareketli dönemde Anadolu'da dokunmuş halıların desenlerinde hayvan motiflerinin çoğaldığı görülmektedir.

Buna ek olarak Bige Çetintürk; yıllardır araştırma yapan Prof. Kurt Erdmann, V. Joseph Mc. Mullan ve Prof. Richard Ettinghausen'in Türk Halıcılığı hakkında şimdiye kadar bilinenlerden başka hiçbir yeni bilgi elde edemediklerini yazmıştır (Çetintürk, 1963, s. 11). Kurt Erdmann bu konuda "Yeni bulgular ve yeni gözlemler, resmi tekrar tekrar değiştirebilir. Oryantal halıyı çok iyi bildiğimizi ve temelde hala onun hakkında çok az şey bildiğimizi düşündüğümüz büyüleyici şey bu" (1966, s. 11) diye görüş bildirmiştir.

Ayrıca yakın dönemde Tibet'te tesadüfen bulunan dört adet hayvan motifli Anadolu halısı vardır. Bu halılar, 14. yüzyıla tarihlenmekte ve günümüzde Heinrich ve Waltraut Kircheim'e ait Orient Stars (Doğu Yıldızları) Koleksiyonunda bulunmaktadır (Mills, 1994, s. 25-26). Tibet'te bulunan hayvan motifli halıarın Anadolu'da sipariş üzerine dokunduğu ve Anadolu hayvan motifli halılarının erken örneklerinden olduğu kabul edilmektedir. Bu halılar, malzeme, teknik, renk ve desen kompozisyonları ile Anadolu'da dokunmuş Anadolu Selçuklu halılarına benzemektedir. Halılardan alınan parçalara uygulanan Karbon 14 testine göre, bu halıların Anadolu yünü ile dokunmuş olduğu tespit edilmiştir (Ölçer, 1997, s. 16-23). 


\section{arts}

\section{Hayvan Motifli Halılarda Motif ve Desen Özellikleri}

Bu dönemde Italyan ressamların tablolarında en çok resmedilen hallır; geometrik şekilli bölümlerin içine geometrik olarak stilize edilmiş hayvan motifleri yerleştirilmiştir. Hayvan motifli halılar, Avrupalı ressamların tablolarında genellikle Meryem'in tahtı altında ya da yere serili olarak resmedilmişlerdir. Resimlerdeki halıarın bazılarının asıllarına uygun, bazılarının ise desenlerinde değişiklikler vardır. Tablolarda desenlerinde değişik olan bazı halılarda geometrik bölümler tamamen kaldırılarak hayvan motifleri yan yana ya da üst üste raportlanmıştır (Görsel 1). Bu hallıarda motif olarak ejder, kuş gibi stilize edilmiş figürler oldukça basit bir şekilde resmedilerek farkı eksenlerde tekrarlandığı görülmektedir. Bazı ressamların tablolarında önden ya da yandan olarak betimlenmiş tek ya da çift başıl kartallar dikkat çekmektedir.

14.-15. yüzyıl Anadolu hayvan motifli halıarın desen kompozisyonları incelendiğinde, dönem halıları beş grupta toplanmaktadır:

1. Hayvan motiflerinin tam raport halinde yerleştirilerek oluşturulan desen kompozisyonu (Görsel 1)

2. Halı ortasının kareler ile bölümlenmesi ve kare içlerine simetrik hayvan motifi yerleştirilerek oluşturulan desen kompozisyonu (Görsel 2)

9.-10. yüzyıl Fustat halı parçalarındaki motif ve desenler, bu gruba örnek olarak verilebilir. Ayrıca bu desen kompozisyonlarında tek ya da çift başlı kartallar ya da tek başına hayvan tasvirleri vardır.

3. Halı ortası iki kareye bölünerek kare içlerine sekizgen, sekizgen içlerine hayat ağacı motifi ile ağaca bakan ya da sıttarı dönük halde kuş ya da ejder motifleri yerleştirilerek oluşturulan desen kompozisyonu

Bu desen kompozisyonuna İsveç'teki Marby Kilisesinde bulunduğu için Marby halısı olarak isimlendirilmiş halı örnek olarak verilebilir (Görsel 3). Önemli hayvan motifli Anadolu hallıarından olan 109x145 cm boyutlarındaki Marby halısı, İsveç Stockholm'de Museum of National Antiquities'de SHM 17.786 envanter numarası ile kayıtlıdır (Lamm, 1985, s. 47, 78). Aynı desen kompozisyonu sistematiği, 16. yüzyıl erken dönem Osmanlı halılarında da görülmektedir.

4. Halı ortası iki kareye bölünerek kare içlerine sekizgen, sekizgen içlerine altta ejderha üstünde ise Anka kuşu motifleri yerleştirilerek oluşturulan desen kompozisyonu (Görsel 4).

5. Tibet'te Budist tapınağında bulunan karşılıklı olarak yerleştirilmiş hayvan motifi içinde hayvan motifi olan halılar (Görsel 5) . 


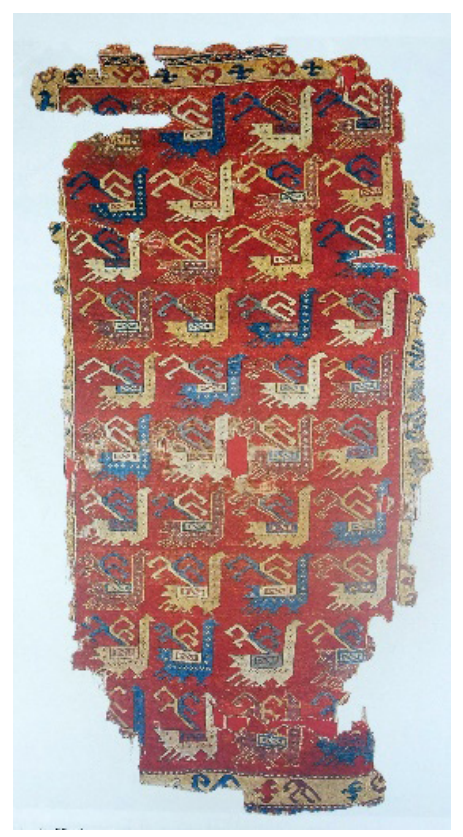

Görsel 1. Ejderha motifli hall, Konya Mevlâna Müzesi. (Aslanapa, 2005: 84)

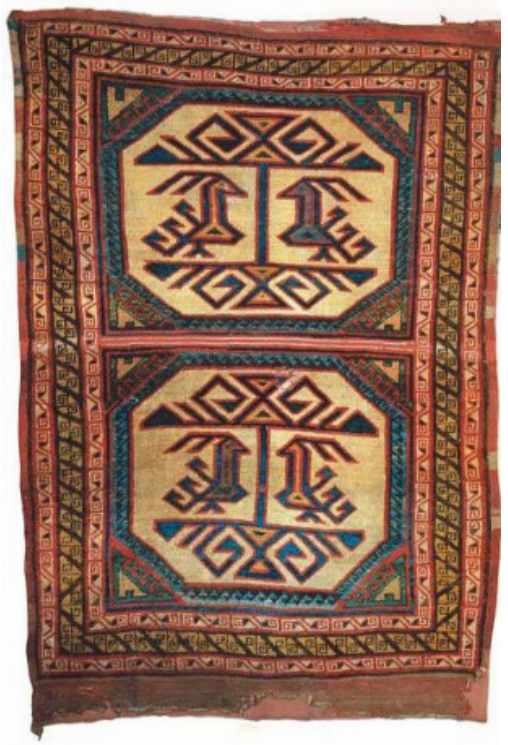

Görsel 3. Marby halısı, Museum of National Antiquities, Stockholm. (Lamm, 1985: 78)

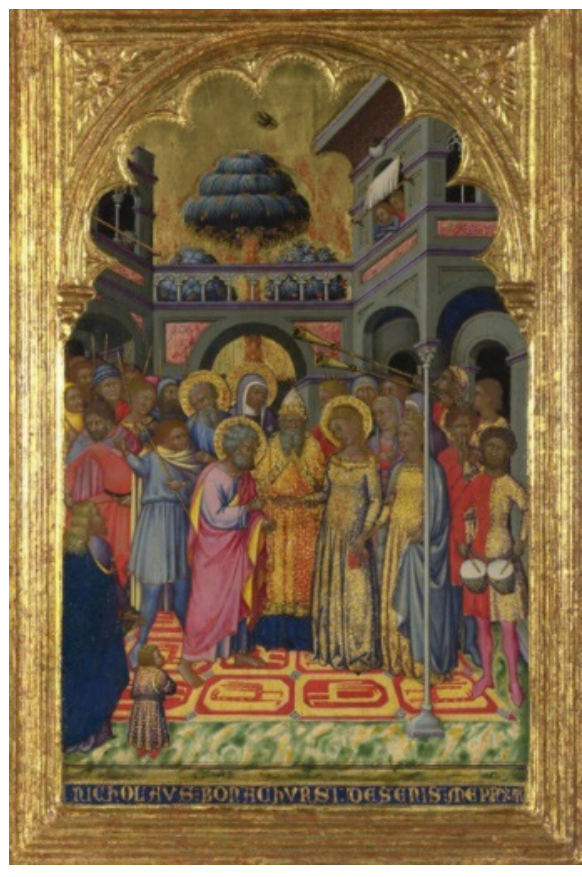

Görsel 2. Niccolò di Buonaccorso'nun "Meryem'in Evlenmesi" (1380), National Gallery, Londra.

(The National Gallery,

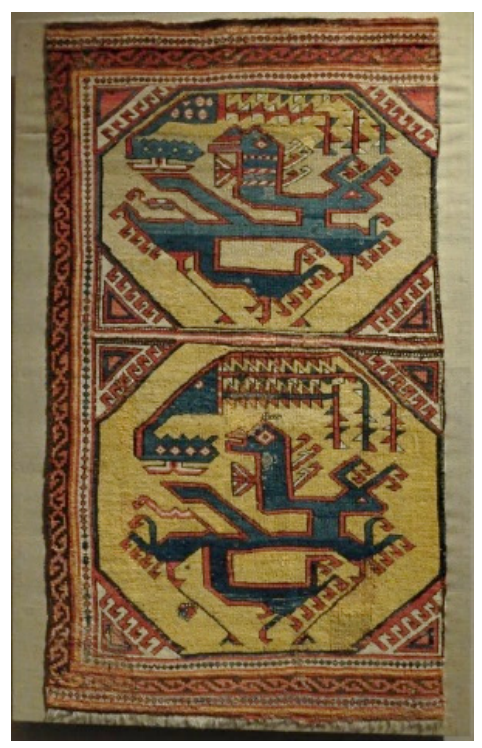

Görsel 4. Ming /Bode halısı, Museum für Islamiche Kunst, Berlin.

Fotoğraf: Servet Senem Uğurlu, 2019. 


\section{arts}

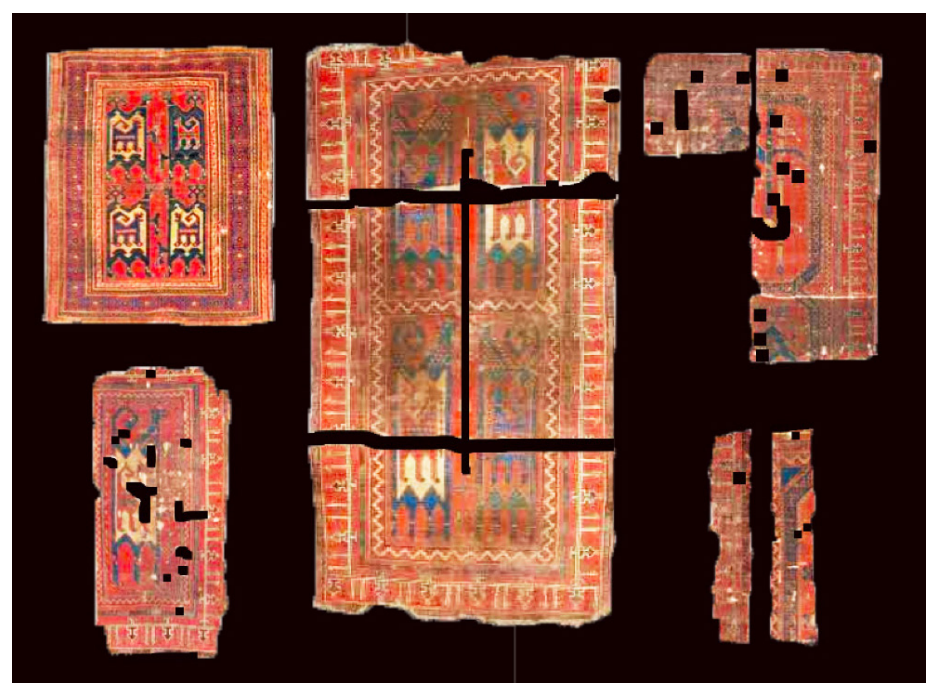

Görsel 5. Kirchheim koleksiyonundaki hayvan motifli halı ve halı parçaları. (Rugkazbah,

Tibet Budist manastırlarının Çin devrim muhafızlarının tahribatı sonrasında, manastırlarda yapılan temizlik sırasında çok sayıda halı manastır yanındaki nehre atılmış, ancak halıların çevredeki dallara takılması ile bazı halılar bulunmuştur. 1990 yılında Nepal'den Londra sanat piyasasına bir grup hayvan motifli halı satışa sunulmuştur. New York Metropolitan Museum tarafından satın alınan bir halının karbon 14 testi sonuçlarına göre, halının tarihi 12.-13. yüzyıl çıkmıştır. Bu halıya benzer bir başka halı tasviri, Londra' daki National Gallery' deki 15. yüzyıl erken dönem Siena Ekolu tablosunda resmedilmiştir. Halının deseni ve resimdeki halı tasvirinin aynı olması oldukça ilginçtir (Aslanapa, 2005, s. 96-106).

Nazan Ölçer'in belirttiğine göre; 1990 yllı sonunda Londra'da antika halı ticareti ile uğraşan bir kişi, elinde Tibet'ten gelen bir halı parçasının olduğunu belirterek Türk ve İslam Eserleri Müzesi' ne başvuru yapmıştır. Karbon 14 testi sonucunda halı, 13. yüzyıl sonu-14. yüzyıl başına tarihlendirildiği ve malzeme analizlerinin Anadolu yünü kökenli olduğunu belirtmiştir. Eğer Türkiye yurtdışından eser alıyorsa, bu eseri ilk olarak Türkiye'ye teklif edeceğini yazmıştır. Uzun yazışmalar sonucunda dönemin Kültür Bakanlığı bütçesinde yeterli kaynağın olmayışı nedeniyle halı alınamamıştır (1997, s. 20-23). Oktay Aslanapa ise; bu hayvan figürlü halıların 13. yüzyılda dokunduğunu ve Anadolu Selçuklularına ait olduğunu belirtmiştir. (1997, s. 14)

Halıda, Ejder ile Anka Kuşunun savaşı betimlenmiştir. Ayrıca İsviçre'de Basel Völkerkunde Museum'a Fustat'tan gelmiş Ming halısı örneğine benzer bir halı 
parçası vardır. Halı parçasının üstündeki motifler, Kurt Erdmann Fustat'tan Ming halı parçasının eksik parçalarından deseninin tamamlanması için yaptığı restitüsyon denemesinde ejder ve Anka kuşunun olduğu sekizgen içindeki motif grubunun, halı eninde 2, boyunda ise 4 kez tekrar ettiğini düşünmüştür. Erdmann, dikdörtgen biçimde olduğunu düşündüğü bu halının büyüklüğünü, $290 \times 360 \mathrm{~cm}$ boyutlarını olabileceğini tahmin etmiştir (Aslanapa, 2005, s. 72).

14. yüzyıl sonunda hayvan motifli halılar zenginleşmiş ve çoğalmıştır. Marby halısından sonra 15. yüzyıl ilk yarısına tarihlenen ve desenlerinde hayvan mücadelelerinin olduğu halılar bulunmuştur.

\section{İtalyan Tablolarında Hayvan Motifili Halıar}

Hayvan motifli halı grubu ilk olarak Sienalı ve Floransalı İtalyan ressamların tablolarında resmedilmiştir. Tablolardaki ilk halılar, geometrik üslupta stilize edilmiş kuş motiflerinden oluşmaktadır. Bu tabloların sayesinde günümüze ulaşmış çok sayıda halı parçasının tarihlendirilmesi ve gruplandırıması yapılmıştır (Aslanapa, 2005, s. 65). En erken İtalyan resimleri olan bu tablolarda, çoğu Siena ve Floransa okullarında Simone Martini ile 1317'de başlamıştır. Bu tarz etkinin ise 15. yüzyıl ortasına kadar devam ettiği görülmektedir. 14. yüzyıl İtalyan tablolarında betimlenen Doğu halıları, ressamlar tarafından belgelenmiştir. Dönemin sanatçıları, Mediciler gibi sanat hamisi ailelerin istekleri doğrultusunda yaptıkları tablolarında, bu halıları resmetmiştir. Doğu halılarında resmedilen motifler, İtalyan süsleme sanatları gelişimine de neden olmuştur. Bazı halılarda geometrik bölümler tamamen kaldıılarak hayvan motifleri tam raportlar halinde olacak biçimde yatay ve dikey doğrultuda raportlanmıştır. Tablolarda geometrik üslupta stilize edilmiş kuş, ejder gibi motifler sıklıkla kullanılmıştır.

Venedik ve Anadolu Selçukluları, 1220 yılında ticari ilişkiler kurmuşlar ve 13. yüzyılda Anadolu'da dokunmuş geometrik motifli halılar dokunarak ihraç edilmiştir. Ünlü gezgin Marco Polo, Konya çevresinde dokunan halıların, dünyanın en güzel ve kaliteli halıları olduğunu yazmıştır (Mack, 2005, s. 128). Bu dönemde Anadolu halıları İtalya' da kraliyet ailesi ve seçkinler için statü simgesi olarak kabul edilmiştir. Lorenzo dei Medici'nin 1492 yılındaki mal varlığı envanter kayıtlarında, değerleri 70 ve 30 florin olan geometrik desenli masa halıları, 60 florin değerinde başka bir geometrik desenli hall; 30 ve 20 florin değerinde Medici hanedan armalı geometrik desenli halılar kaydedilmiş olduğu bilinmektedir (Mack, 2005, s. 126-127). 


\section{$\operatorname{arts}=$}

Tabloların yapılış tarihleri üzerinde olduğu ya da bilindiği için, tarihler sayesinde Doğu halılarının desen değişimleri kolaylıkla gözlemlenmiştir. İtalyan ressamlar tarafından 14. yüzyılda başlayan halıların tablolarda resimlenmesi, 16. yüzyıla kadar daha da artmıştır. İtalyan resim üslubundaki bu değişim, geometrik desenli yüksek kaliteli halıların İtalya'ya ihracı ve zenginlerin gösteriş, saygınlık, prestij için lüks evlerine satın aldıkları halılar ile bağlantııdır.

\section{Ming Halılarının Resimlendiği Tablolar}

Ejderha ve Anka kuşu mücadeleli halılar; italyan ressam Domenico di Bartolo'nun Bulunan Çocukların Kabul Edilişi ve Evlendirilişi freski ile italyan Rönesansı' nın gotik ressamı Bartolomea degli Erri Vincent Ferrer Hayatından Sahne: Deli Annesi Tarafından Parçalanmış ve Kızartılmış Çocuğun Resüsitasyonu isimli tablolarında resmedilmiştir.

Italyan ressam Domenico di Bartolo'nun Siena'da Santa Maria della Scala Hastanesi Şapeli Bulunan Çocukların Kabul Edilişi ve Evlendirilişi (1441-1442) freskinde tasvirlenen motif, Ming halısındaki ejderha ve Anka motiflerine benzemektedir ve sekizgen içerisindeki motif grubu halının eninde iki kez tekrar ettiği görülmektedir (Görsel 6, Görsel 7).

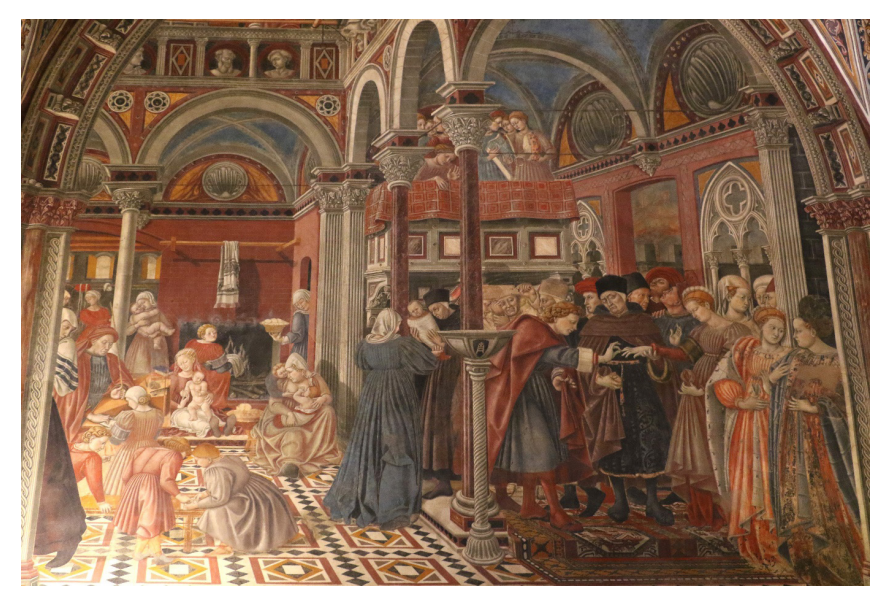

Görsel 6. Domenico di Bartolo, "Bulunan Çocukların Kabul Edilişi ve Evlendirilişi" (144 1-1442) freski, Fotoğraf: Raffaele Pagani, Oppadale S. M. Della Scala. (Flickr, 23 Ağustos 2016) 


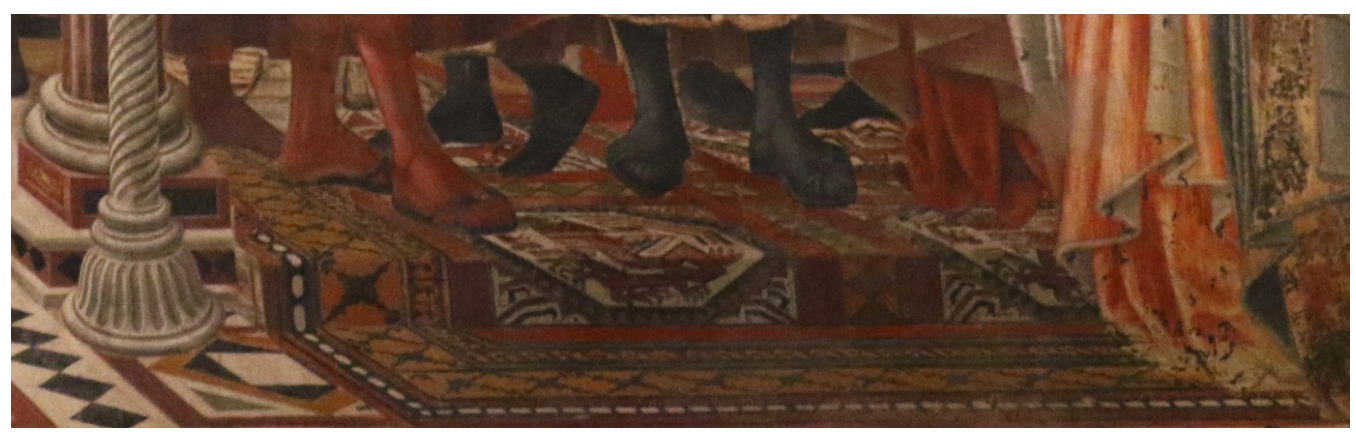

Görsel 7. Domenico di Bartolo'nun "Bulunan Çocukların Kabul Edilişi ve Evlendirilişi" adlı tablonun ayrıntısında Ming halısı. Fotoğraf: Raffaele Pagani, Oppadale S. M. Della Scala.

(Flickr, 23 Ağustos 2016)

Italyan ressam Bartolomea degli Erri tarafindan yapılan ve 1450-1475 yilları arasında tarihlenen $60,5 \times 35,5 \mathrm{~cm}$ boyutlarında bu tablo, Avusturya'nın Viyana kentindeki Kunsthistorisches Museum Wien Gemäldegalerie'de GG_6696 envanter numarası ile kayıtlıdır. Türkçe kaynaklara Aziz Vincent Ferrer Efsanesi'nden Bir Sahne ismi ile geçmiştir. Oysa tablonun asıl adının, Vincent Ferrer Hayatından Sahne: Deli Annesi Tarafından Parçalanmış ve Kızartılmış Çocuğun Resüsitasyonu olduğu tespit edilmiştir (Kultur Pool,

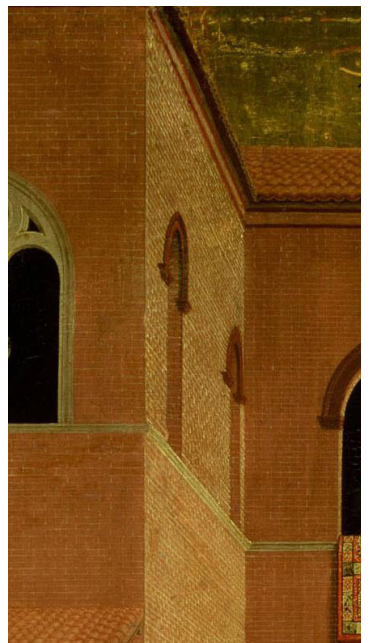

Görsel 8. Ressam Bartolomeo degli Erri'nin "Vincent Ferrer Hayatından Sahne: Deli Annesi Tarafindan Parçalanmış ve Kızartılmış Çocuğun Resüsitasyonu" tablosu.

(Kultur Pool,

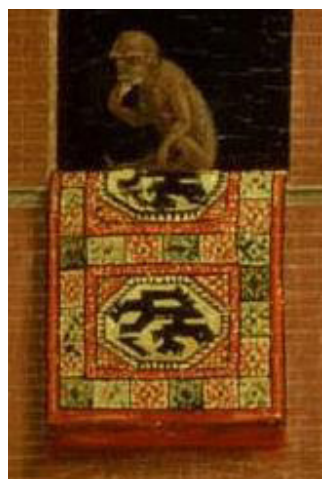

Görsel 9. Ressam Bartolomeo degli Erri'nin "Vincent Ferrer Hayatından Sahne: Deli Annesi Tarafından Parçalanmış ve Kızartılmış Çocuğun Resüsitasyonu" adlı tablosundan ayrıntı. (Kultur Pool, 


\section{arts}

\section{Türk Halıcılığında Bahsedilmemiş Yeni Bir Tablo: St. Thomas Aquinas'ın}

\section{Bebekliği}

Illk olarak İtalyan ressamlar Domenico di Bartolo ve Bartolomea degli Erri'nin Ming halısıyla ilgili başka resimlerinin olabileceği düşüncesi ve varsayımından hareket edilerek iz sürülmüş, bu ressamların elektronik ortamda erişilen müze ve özel koleksiyonlardaki tabloları taranarak incelenmiştir. Türk Halıcılığında şimdiye kadar bahsedilmemiş Ming halısıyla ilgili üçüncü tablo bulunmuştur.

Tüm bu bilgilere ek olarak, Staatliche Museen zu Berlin-Preussischer Kulturbesitz tarafından 1929 yılında basılmıs Jarbuch der Preuszischen Kunstsammlungen adlı müze kitabında, Kurt Erdmann'ın Orientalische Tierteppiche auf Bildern des XIV. und XV. Jahrhunderts başlıklı 38 sayfadan oluşan bir kitap bölümü vardır. Bu kitap bölümünde, sayfa 284 'te bulunan 33 numaralı görseldeki tablonun açıklaması olarak "Baldovinetti, Madonna, Jarves Collection, New Haven" yazıımıştır (Erdmann, 1929, s. 284). Bu açıklamanın yanlışlıkla yazıldığı düşünülmektedir.

İtalya'nın Modena şehrindeki San Domenico Kilisesi için, Bartolomeo degli Erri tarafından tahmini olarak 1470 yılında yapılmıs panel üzerine tempera ve altın ile resimlenmiş, 32,7 x $44 \mathrm{~cm}$ boyutlarındaki tablo, San Domenico Kilisesinde St. Thomas Aquinas'a adanmış 15. yüzyıl sunağındaki muhtemelen dokuz sahneden oluşan bir grup resmin parçasıdır. Bu resim grubu, Bartolomeo degli Erri (Modena, 1447-1482) ve ağabeyi Agnolo degli Erri (1440-1482) tarafından yapılmıştır. Kilise 1708 yılında yıkıldıktan sonra yeniden inşa edilirken, resimlerin o dönemde farklı yerlere dağılmış olduğu anlaşılmaktadır (Wikiwand, __).

Resimler önceleri İtalya Toskana bölgesi Floransa kentinde J. J. Jarves Koleksiyonu'nda iken günümüzde Amerika Birleşik Devletleri Connecticut Eyaleti, New Haven'daki Yale Üniversitesi Sanat Galerisi'ndedir. Araştırma sırasında, Bartolomeo degli Erri'nin St. Thomas Aquinas'ın Bebekliği adlı tablosu ile ilgili ilk görsel, ressam Bartolomeo degli Erri ve Agnolo degli Erri kardeşler tarafından yapılmış 1470 tarihli St. Thomas Aquinas'ın Çocukluğu adlı tablonun ayrıntısıdır (Görsel 10, Görsel 11). Adı geçen tablo, Italya'da Federico Zeri Vakfı tarafından Zeri \& LODE Projesi ile PHAROS uluslararası fotoğraf arşivleri konsorsiyumu bağlamında Bologna'daki Fondazione Federico Zeri Üniversitesi Fotoğraf Kütüphanesi Kataloğunda siyah-beyaz fotoğraf halinde olduğu görülmüş, renkli fotoğrafı ise Bartolomeo degli Erri'nin St. Thomas Aquinas'ın Bebekliği tablosu, Yale Üniversitesi Sanat Galerisi'nin 1871.41 no.lu envanterinde bulunmuştur (Wikimedia Commons, 18 Şubat 2018). 


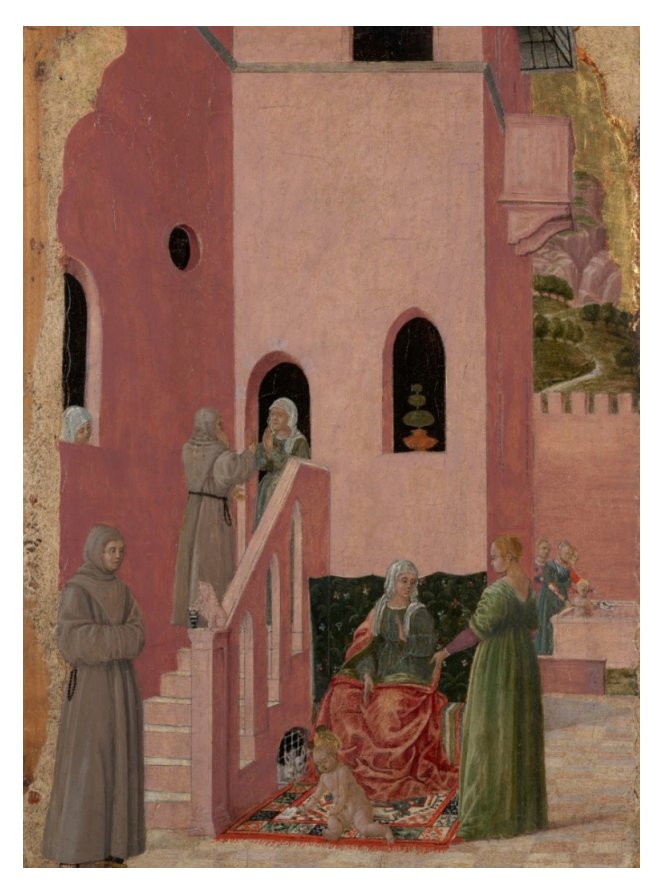

Görsel 10. "St. Thomas Aquinas'ın bebekliği", Bartolomeo degli Erri ve Agnolo degli Erri, Yale Üniversitesi Sanat Galerisi, Envanter No: 1871.41. (Wikimedia Commons, 18 Şubat 2018)

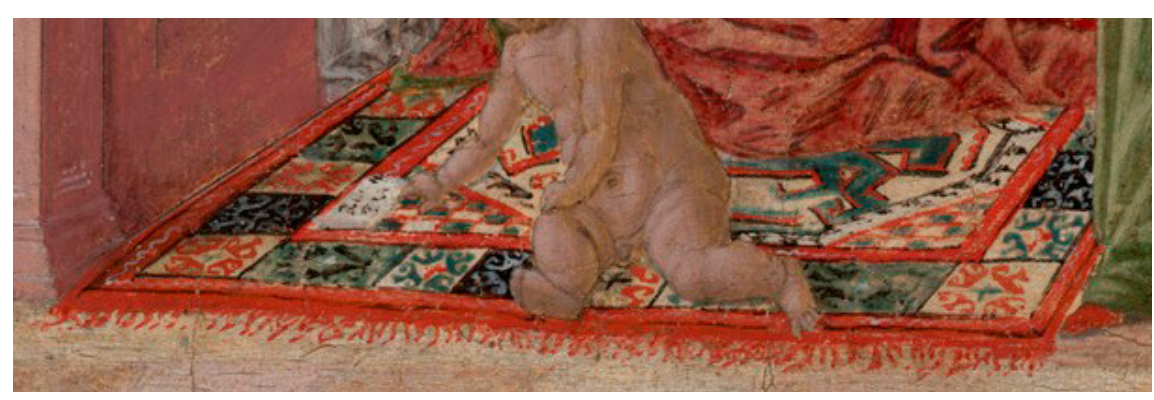

Görsel 11. Bartolomeo degli Erri'nin "St Thomas Aquinas'ın Bebekliği" adlı tablosunun ayrıntısı. (Wikimedia Commons, 18 şubat 2018)

Bu tabloda resimlenen halının ortasında sekizgen içerisinde ejderha ve Anka kuşunun olduğu (Görsel 9) ve geniş kenarsuyunda İstanbul Türk ve İslam Eserleri Müzesi koleksiyonunda bulunan 365 envanter numaralı Batı Anadolu Bergama halısının (Turkish Republic Ministry of State - Ministry of Culture, 1992, s. 0012) ortasındaki elibelinde motiflerinin olduğu motif grubu görülmektedir (Görsel 11, Görsel 12, Görsel 13). 


\section{arts}

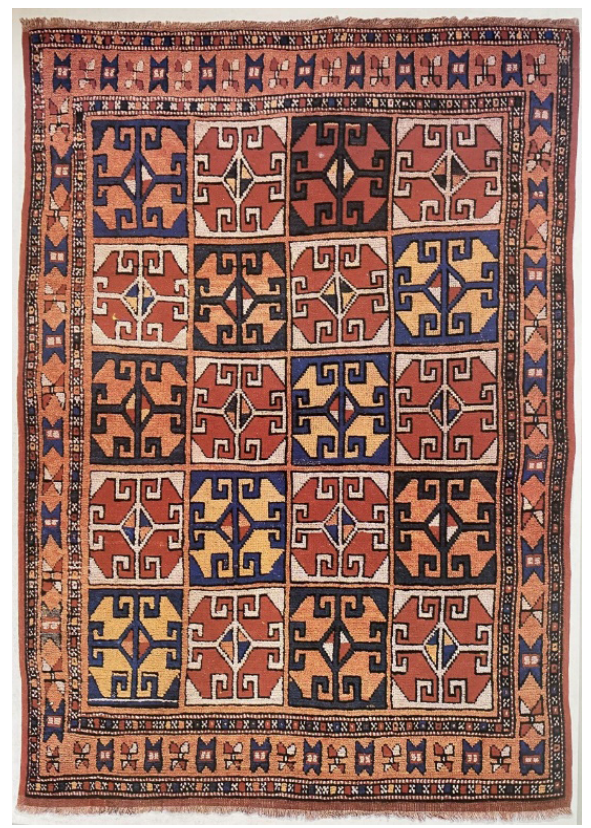

Görsel 12. Bergama halısı, Türk ve islam Eserleri Müzesi

(Turkish Republic Ministry of State - Ministry of Culture, 1992: 0012)

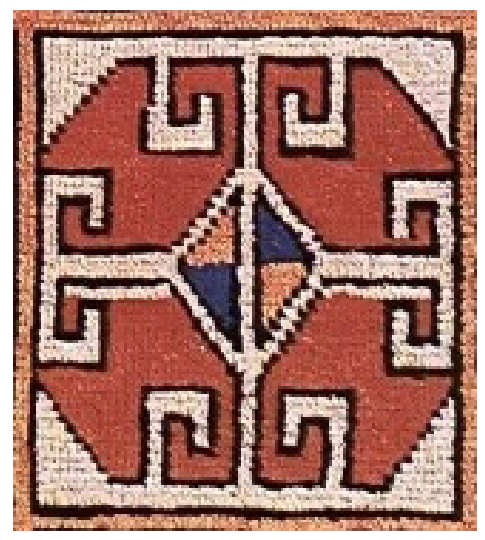

Görsel 13. Bergama halısındaki Elibelinde motifi, (Turkish Republic Ministry of State - Ministry of Culture, 1992: 0012)

\section{Ming Halısı}

Orta İtalya'da bir kilisede bulunan ve Roma'da bir antikacıya satılan Ming halısı, 1890 yılında Alman Wilhelm von Bode tarafından müze için satın alınarak (Enderlein, 1995, s. 23; Beselin, 2011 , s. 46) Berlin İslam Sanatları Müzesi'ne bağışlanmıştır (Enderlein, 1995, s. 23). Ming halısı, Wilhelm von Bode tarafından bulunduğu için, öncelikle "Bode halısı" olarak isimlendirilmiş ve tanınmıştır. Ming halısı, 13. yüzyıl Anadolu Selçuklu halıları ile M.Ö. 4. yüzyıl Pazııık halııının keşfine kadar "dünyanın en eski halısı" olarak tanıtılarak sergilenmiştir (Aslanapa, 2005, s. 71).

Hayvan motifli Anadolu halıları grubunda en sağlam kalmış halıdır. Ming halısı, Almanya Berlin' de Pergamonmuseum'un İslam Sanatı Müzesinde, 1865 ylında oluşturulan koleksiyonun içerisindedir. 1906 yılında İslam Bölümü'ne devredildiğinde, Ming halısının Kunstgewerbemuseum'daki envanter numarası KGM 1886.603'tür. İkinci Dünya Savaşı sırasında bombalanan ve büyük zarar gören müzenin restorasyonu çok uzun süre devam etmiştir. Galeri, 2018 yılının Ekim ayı sonunda yeni haliyle ziyarete açılmıştır (Hali, 7 Ocak 2019).

Anadolu'da dokunmuş olduğu bilinen Ming halısı, günümüzde Museum für Islamische Kunst-Staatliche Museen zu Berlin (Berlin İslam Sanatları Müzesi) 
Koleksiyonunda, müze bilgilerine göre 15.-16. yüzyllara tarihlendirilmekte ve müzede I.4 envanter numarasıyla kayıtlı olarak korunmakta ve sergilenmektedir. Müze kayıtlarına göre; kalitesi 22x26 ilme/dm² olan halının boyutları 91×164cm'dir. Halının çözgü, ałkı ve ilmelerinde malzeme olarak yün kullanılmıştır. Ming halısı, Türk ilmesi ile dokunmuştur (Görsel 14). 1999 yılında yapılan radyokarbon / karbon 14 testine göre halı parçası 1486-1645 yıllarına tarihlendiği bilinmektedir (Beselin, 2018, s. 50).

Berlin Kunstgewerbemuseum koleksiyondaki önemli halıların çoğu, 1872-1892 yılları arasında Julius Lessing ile Wilhelm von Bode tarafından toparlanmıştır. Halılar, önceleri Kunstgewerbe Museum ile Wilhelm von Bode'nin özel koleksiyonunda korunmuştur (Kröger, 2007, s. 113). 1906'te Wilhelm von Bode özel koleksiyonundan yaklaşık 20 halıyı Berlin İslam Eserleri Müzesi'ne sunmuştur. Müze ve koleksiyonlardaki halılar ne kadar sağlam görünseler de günümüze ulaşmaları çoğunlukla tesadüfler sayesinde olmuştur. Bode ve Lessing koleksiyon halılarını satın alırken belirli bir plana göre yapmamış, pazarda denk gelen fırsatlara göre ilginç ve nadir Türk halılarını gördüklerinde satın almışlardır (Faroqhi, 2018, s. 77). Motif ve desen kompozisyonlarına dikkat ederek ilginç buldukları halıları, ne olduklarını bilmeseler bile almayı tercih etmişlerdir. Bazı halıların desenlerinin tablo ve fresklerde resmedilmiş olduklarını fark ettikleri için halıarın ne zaman dokunmuş olabileceklerini tahmin etmişlerdir. Bütün haldeki halıları satın almalarının yanı sıra halı parçalarını da satın aldıkları görülmektedir. Kullandıkları bu yönteme, araştırmacılar tarafından "Berlin Okulu" adı verilmiştir (Kröger, 2007, s. 118). Lessing'in İstanbul, İtalya ve Almanya'dan, Bode'nin ise genellikle İtalya'dan özellikle Floransa ve Roma şehirlerinden halı satın aldığı düşünülmektedir. Bode'nin Floransa'da resim ve heykel konusunda güvenilir bir kaynak olan Stefano Bardini'nin yardımıyla halı satın aldığı, Floransa'da A. Salvadori'nin, Venedik'te ise Carl Zuber'in müşterisi olduğu bilinmektedir (Kröger, 2007, s. 118).

Ming halısının desen kompozisyonu incelendiğinde; halı ortası iki kare alana bölünmüştür. Karelerin içerisinde bulunan sekizgen şekil içerisinde Ejderha ve Anka kuşu mücadelesi geometrik olarak stilize edilmiş motifler olarak görselleştirilmiştir. Halıda üstteki kare alanın alttakine göre daha basık dokunduğu görülmektedir. Bunun yanı sıra halının sağ tarafında dikey bordürler eksiktir. 


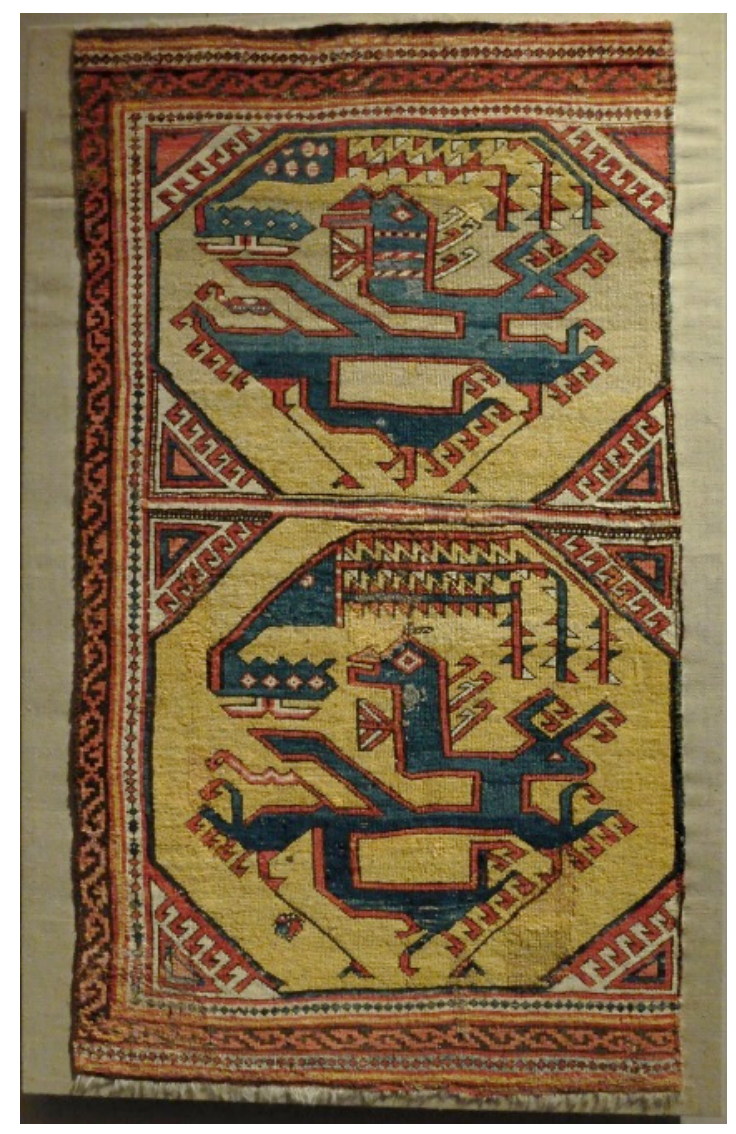

Görsel 14. Ming (Bode / Ejder ve Anka Kuşu motifli) hall, Berlin İslam Sanatları Müzesi, Envanter No: I.4. (Fotoğraf: Servet Senem Uğurlu, 2019)

Michael Franses, Ming halısı hakkında düşüncelerini şu şekilde ifade etmiştir: Wilhelm von Bode; Ming halısının dikey bordürlerinden birinin kaybolduğu ve parça halinde olduğu için; bu halının iki kareden mi yoksa daha büyük bir halının parçası mı olduğu hakkında kesin bir sonuca varamamıştır. Ayrıca "S" motifli bordür iki kare arasında devam ederek iç bordürü oluşturuyorsa, o zaman halı daha büyük bir halının bir bölümü olabilir diye düşünmüştür. Halı incelediğinde ise, halının desen kompozisyonunun iki tekrardan oluştuğu görülmektedir (2007, s. 45-48) diye görüş bildirmiştir.

Michael Franses, Ming halısının deseninden iki örnek daha olduğunu belirtilmiştir. İlk örnek, İtalya'da özel bir koleksiyonda (Görsel 15) ve Ming halısı ile karşılaştııılığında anlaşılabilmektedir (2007, s. 45).

Oktay Aslanapa, Kahire antika pazarında bulunan bu halı parçasının bordürlerinin kufi benzeri ve orta deseninin Ming halısına benzediğinden ve Kurt Erdmann'ın bu halı parçasını tamamlama denemesi (Çizinh) yaptığından 
bahsetmiştir (1987, s. 40-41). Anadolu'da dokunmuş olduğu tespit edilen bu halı parçası, 14. yüzyıl erken dönemine ait olup 48x66 cm boyutlarındadır. Ejderha ve Anka motifli bu halı parçası Sotheby's New York' †a 17 Eylül 1992 tarihinde tahminen 10.000-20.000 Amerikan doları başlangıç fiyatıyla açık arttırmaya girmiş (Marketplace News, 1992, s. 162-163) ve 68.750 Amerikan dolarına satımıştır (Rugtracker, 27 Ocak 2021). Araştırmadaki halı parçasının restitüsyon eskizi ise yazar tarafından yapılmıştır.
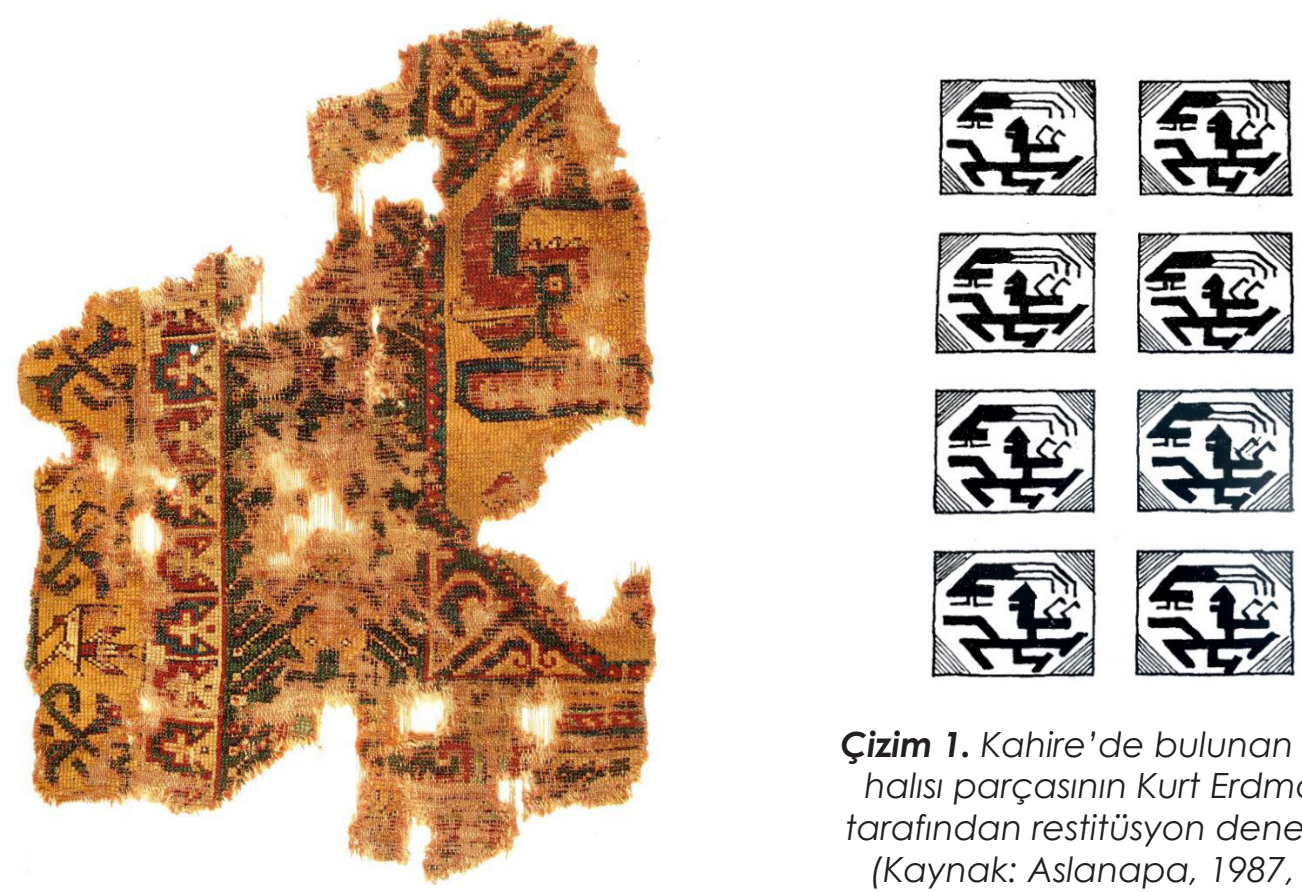

Çizim 1. Kahire'de bulunan Ming halısı parçasının Kurt Erdmann tarafından restitüsyon denemesi (Kaynak: Aslanapa, 1987, 41)

Görsel 15. Kahire antika pazarı bulunan kufi yazı benzeri bordürlü Ming halı parçası. rugtracker.com/2021/01/ (Erişim tarihi: 06 Haziran 2021)

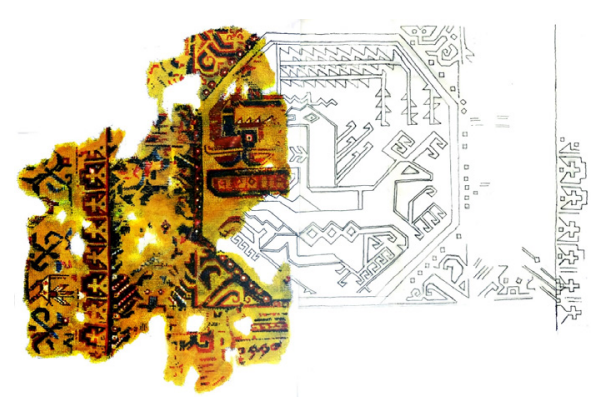

Çizim 2. Kahire'de bulunan Ming halısı parçasının restitüsyon denemesi. (Çizim: Servet Senem Uğurlu, 2021) 
Michael Franses'e göre ikinci örnek ise, İsviçre Basel eski adıyla Wölkerkunde Museum yeni adıyla Museum der Kulturen Basel'de korunmakta olup küçük bir parça halindedir (Görsel 16). Bu parçanın Fustat'tan geldiği bilinmektedir. Museum der Kulturen Basel'deki bu parça ile Ming halısı karşılaştııılığında, Ming halısı parçası olduğu kolaylıkla anlaşılmaktadır (Aslanapa, 2005, s. 72; Franses, 2007, s. 45).
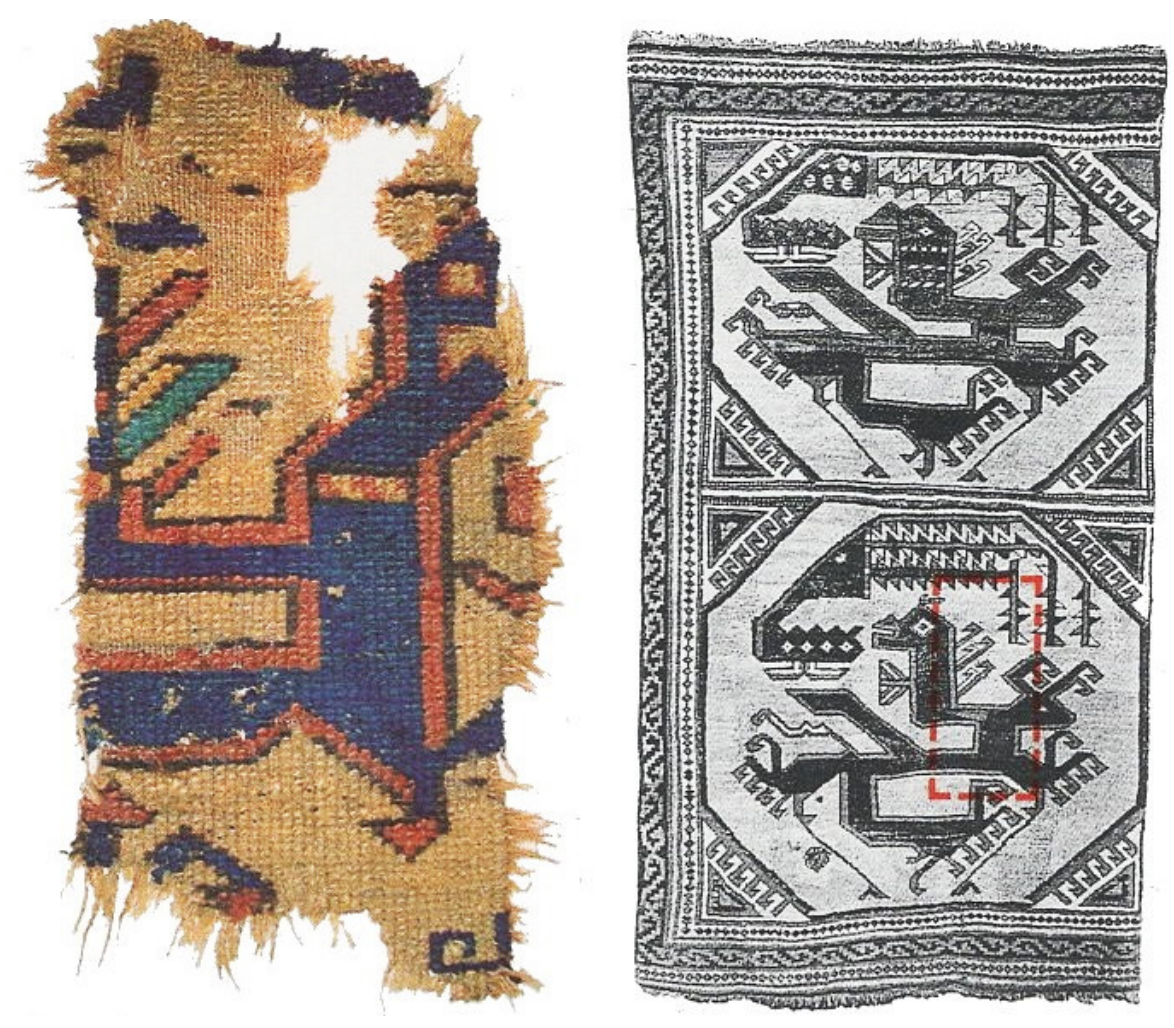

Görsel 16. Basel Wölkerkunde Museum'da bulunan Ming halısı parçası. (Rugtracker, 27 Ocak 2021)

Tüm bunlara ek olarak, daha önce bahsedilmemiş bir Ming halısı parçası örneği daha bulunmaktadır (Görsel 17). Bu halının Almanya Berlin'de bulduğu ve 1980'li yıllarda saldırıya uğrayan bir Ming halısı parçası olduğu bilinmektedir (web 6). 


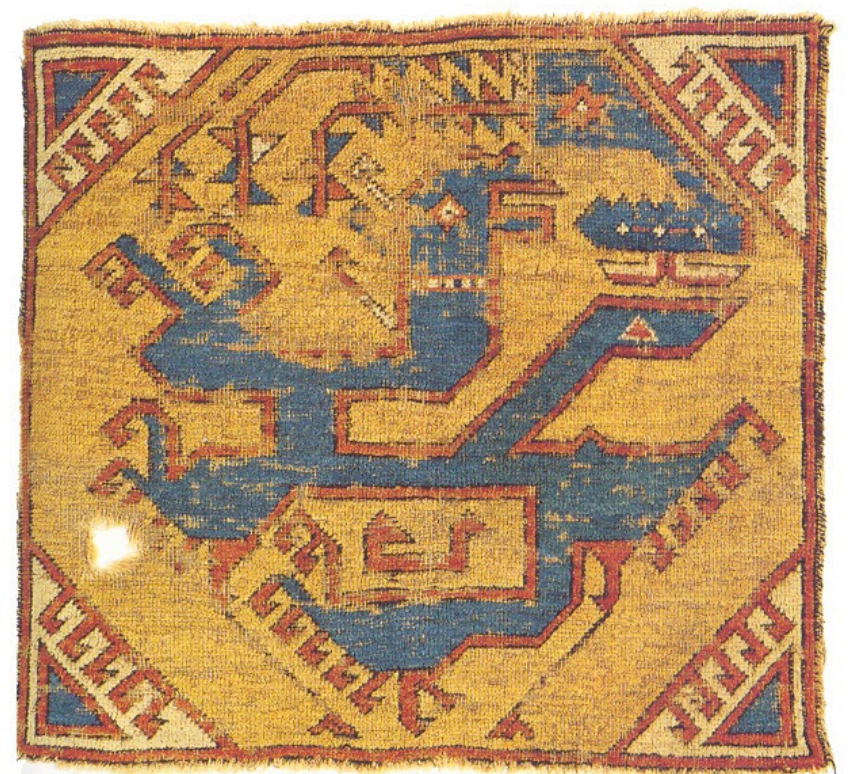

Görsel 17. Berlin'de bulunan ve 1980'li yıllarda saldırıya uğrayan Ming halısı parçası. (Rugtracker, 27 Ocak 2021)

Bu halıda tespit ettiğim en önemli özellik; diğerlerinden farklı olarak Anka kuşunun gövdesindeki altı köşeli yıldız motifidir (Görsel 17, Görsel 18). Ayrıca Ejderha ve Anka kuşu mücadelesi, diğer Ming halıları ile karşılaştııılığında, ayna simetrisinde dokunmuş olduğu görülür.

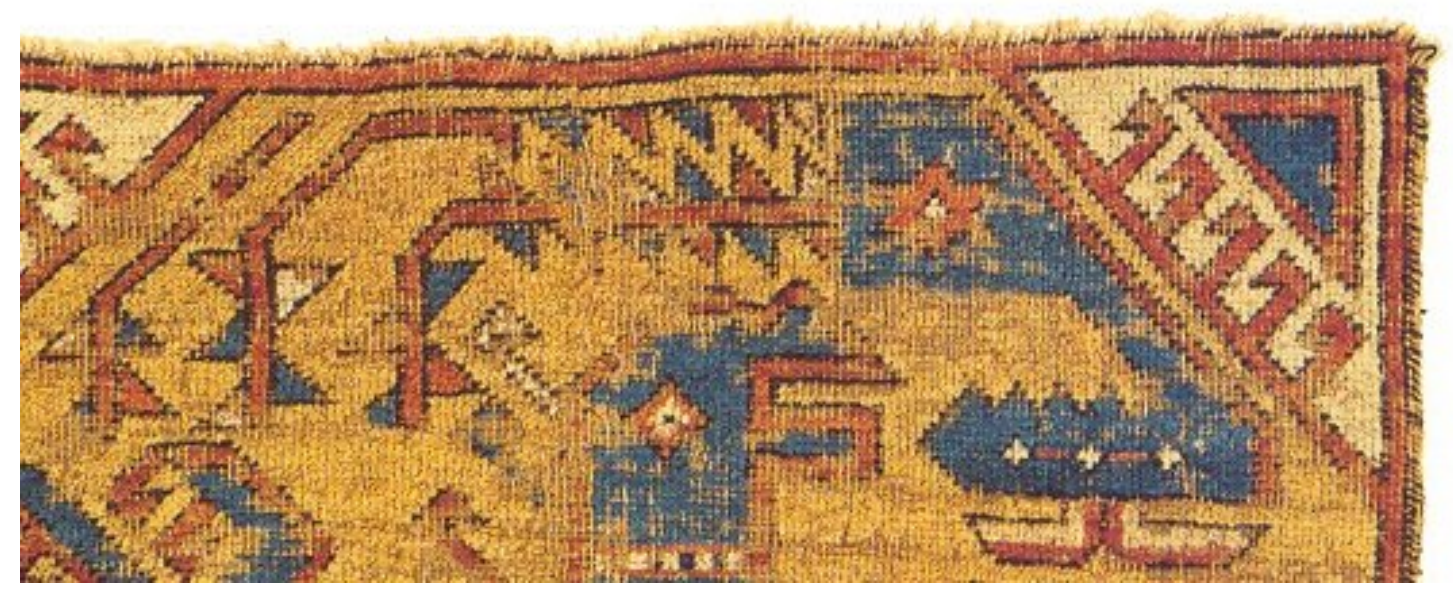

Görsel 18. Görsel 16'daki Berlin'de bulunan Ming halı parçasının Anka kuşu ayrıntııı ve gövde içerisinde görülen altı köşeli yıldız motifi. (Rugtracker, 27 Ocak 2021)

\section{Ming Halısının Motifleri}

Ming halısının ikonografik ve görsel tasarım disiplinleri altında incelenmesi ve değerlendirilmesi, 14.-15. yüzyı Anadolu hayvan motifli halılarda kullanılan üslubun 
anlaşılmasında önemli bilgiler içermektedir. Hayvan üslubu ikonografisi; belirli hayvan mücadeleleri, önemli saldırı hareketlerinin betimlenmesi ve figürlerin anlamları ile oluşturulmuştur.

Hayvan figürlü halılar kronolojik olarak incelendiğinde; halılar üzerinde kullanılan hayvanların önceleri barışık daha sonra ise kavga eder biçimde olduğu görülmektedir. Anadolu'nun siyasi durumuyla ilgili barış, kavga ve kargaşa durumunun halılara eklenmiş olduğunu ilk fark eden Kurt Erdmann olmuştur (Aslanapa, 2005, s. 65).

Ming halısının tasarımı geometrik temellerle oluşturulmuştur. Bu tasarımın izleri, Anadolu'daki kırsal kesim halı ve kilimleri ile son dönemlere kadar devam etmiştir. Halıdaki tasarım, arabesk çizimlerindeki geometriden çok farklıdır. Halı tamamen asimetrik tasarımla oluşturuımuştur. Ming halısının başka ve benzer örnekleri araştıılarak makaleye eklenmiştir.

Yabancı araştırmacıların dikkatini çeken, Ming halısı sırtında / arkasında halı sıraları arasına 6 santimetrelik aralıklarla, beş çözgü üzerine, kırmızı renkte yün iplikle bir ilme geçirildiği görülmektedir (Görsel 19, Çizim 3). Tespit ettikleri bu özelliği müze uzmanları, dokumacının günlük çalışmasıyla ilgili bir işaret olduğunu düşünmüşlerdir. Aynı işaretlemelerin, Marby halısında da mevcut olduğu bilinmektedir (Beselin, 2018, s. 50-53). Atölye halıcılığında dokuyucunun günlük performansını belirlemek için, nişan adı verilen bu işaretlemeler yapılmaktadır. Bu işaretler, Ming halısının atölye tipi üretimle dokunduğunu göstermektedir. Birden fazla dokumacının bu halıda çalıştığını kanıtlamaktadır.

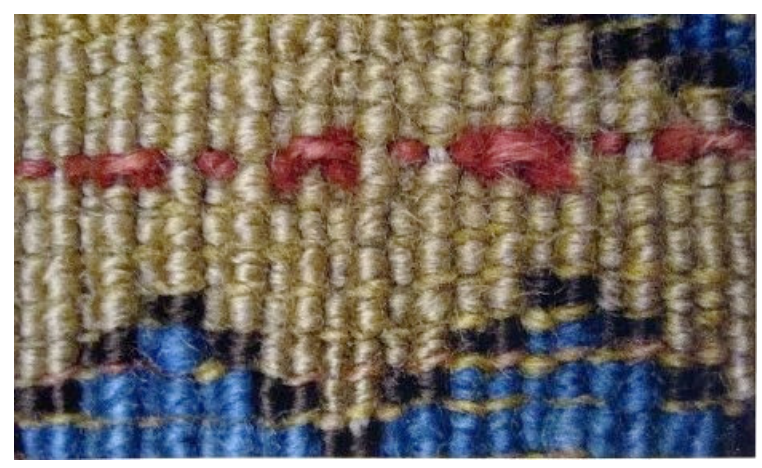

Görsel 19. Ming halısının sırtındaki kırmızı renkli nişan iplikleri, (Beselin, 2018: 53)

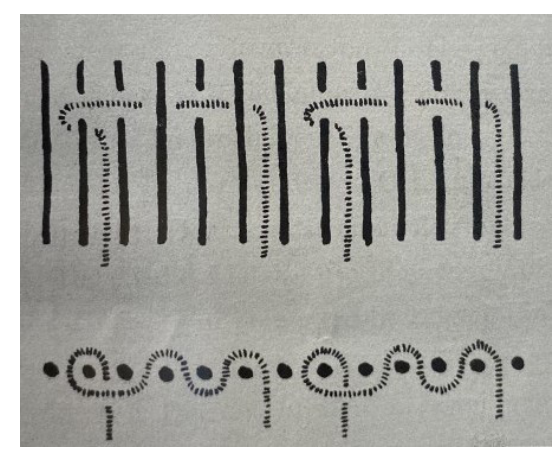

Çizim 3. Ming halısının sırtında görülen nişan ipliğiyle beş çözgü üzerine atılan ilme,

(Beselin, 2018: 53) 
İkonografi temel olarak sonsuzluk ve zamana hakim olmak için yapılmaktadır. Ming halısında yer-gök, iyi-kötü, kadın-erkek, gece-gündüz, savaş-barış, sükûnetkaos gibi ikilem anlamı veren zıtlıkların birleşimi vardır (Eberhard, 2000, s. 105). Çin inancına göre Ejderha eril, Anka dişil ilkeleri temsil etmektedir. İki sembolün bir arada kullanılması ise evliliği simgelemektedir (Eberhard. 2000, s. 106). Anadolu için bu anlam evlilik ya da birleşim olarak ifade edilebilir.

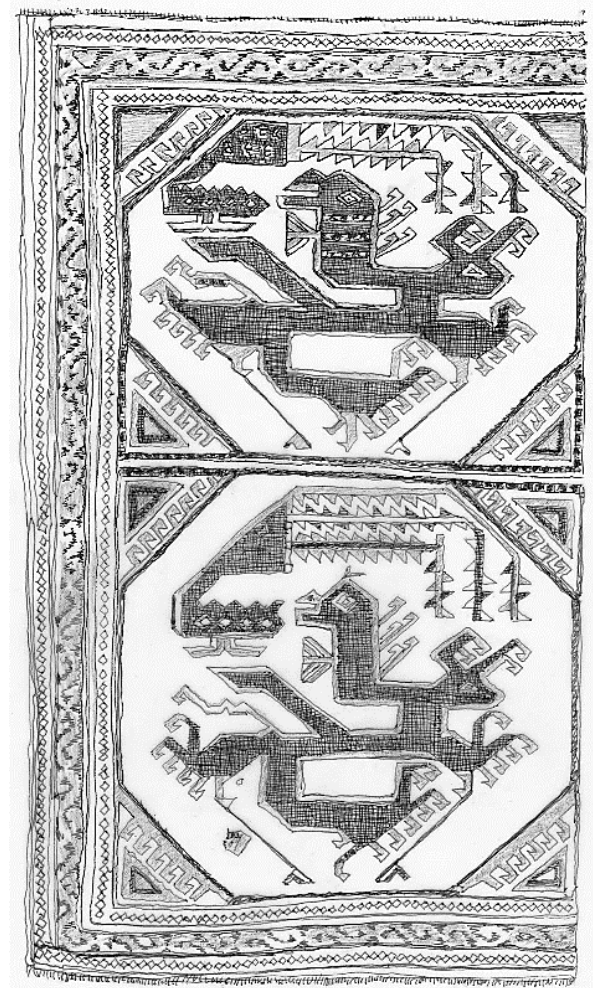

Çizim 4. Ming halısının çizimi (Çizim: Servet Senem Uğurlu, 2021)

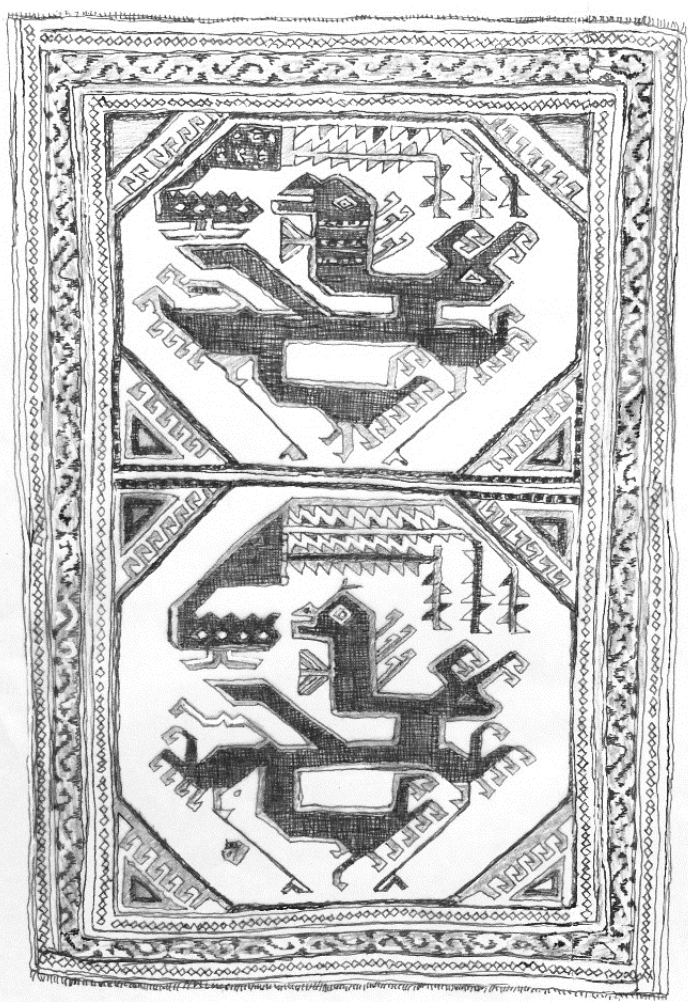

Çizim 5. Ming halısının restitüsyon çizimi (Çizim: Servet Senem Uğurlu, 2021)

Karakteristik desen özellikleri gösteren Ming halısının desen kompozisyonu; ejderha, Anka kuşu, çengel, dört yön ve "S" motifleri ile iç içe üçgen, eşkenar dörtgen, kare ve sekizgen şekillerden oluşmuştur. Ming halısının çizimi ve eksik bordürlerinin restitüsyonu yapılarak çizimi yapılmıştır (Çizim 4, Çizim 5). Üst taraftaki sekizgen ve içindeki ejderha ile Anka kuşu motifleri daha acemice ve motifler daha basık biçimde dokunmuş olduğu görülmektedir.

\section{Ejderha}

Ejderha, çok sayıda mitolojik ve kozmolojik kavramın birleştirildiği, özellikle 


\section{arts}

Orta Asya kültüründe en karmaşık simgelerinden biridir. Ejderha Batı ülkelerinde zarar veren kötü bir varlık iken Doğu'da ise zararsı, iyi huylu bir gerçeküstü varlık olarak bilinmektedir. Ataerkil kültürde ise güç ve verimliliğin simgesi olmuştur (Eberhard, 2000, s. 104).

Ejderha Doğu'yu ve dört elementi simgelemektedir. Ayakları ile toprağı, vücudunun pullu olmasıyla suyu, kanatlarıyla havayı ve ağzından çıkan alevle ateşi temsil etmektedir. Anasır-ı Erbaa olarak Türk kültüründe geçmektedir. Türk Sanatında ejder ikonografisi Emel Esin, Anadolu Selçuklu Sanatında ejder tasvirleri ise Gönül Öney tarafından incelenmiştir.

Emel Esin, Orta Asya Türkçesinde Ejder/Ejderha kelimesine Büke ve Evren gibi isimler verildiğini, hayvan simgeli Türk takviminde bir burç olduğunu, en eski ejderha örneklerinin 6. yüzyıla tarihlendiğini, evren şekillerinin Türk kültürü disiplininde başkalaşımlar geçirdiğini ifade etmiştir. Evren'in felek ve zaman kavramlarıyla birleşerek dünya simgesini oluşturduğunu vurgulamıştır. Gönül Öney, kervansaray, cami, saray, darüşşifa, mezar taşı, kümbet, medrese gibi Anadolu Selçuklularının mimari yapılarında kullanılan ejder motiflerini incelemiştir.

Avrupalı ressamların tablolarında görülen hayvan figürlü halılar, resim içerisinde Meryem' in tahtı altında ya da yere serili olarak resimlenmiştir. Resimlerdeki halıların hepsi asıllarına uygun olmayıp bazılarında değişiklikler vardır. Resimlerdeki halı tasvirlerinden bazılarının halılarına henüz bulunamamış ya da yok olmuştur.

14. ve 15. yüzyıllardan günümüze İran halısı ya da halı parçası kalmamıştır. Illk olarak Ettinhausen ve sonrasında Oktay Aslanapa ve Yusuf Durul tarafından bahsedilen 14. yüzyıl ilk yarısında 1335-1340 yıllarına tarihlenen, Tebriz Okulu ekolüne ait, Washington D.C. Freer Gallery of Art koleksiyonunda F1923.5 envanter numaralı 19,7×24,3 cm boyutlarındaki Demotte (Büyük Moğol) Şehnamesi adlı yazma eserin Iranlılar Arap kral Zahhak'ın tahta geçişi minyatüründe (Görsel 20, Görsel 21, Çizim 6), ejderha motifi resmedilmiştir (Aslanapa ve Durul, 1973, s. 59). 


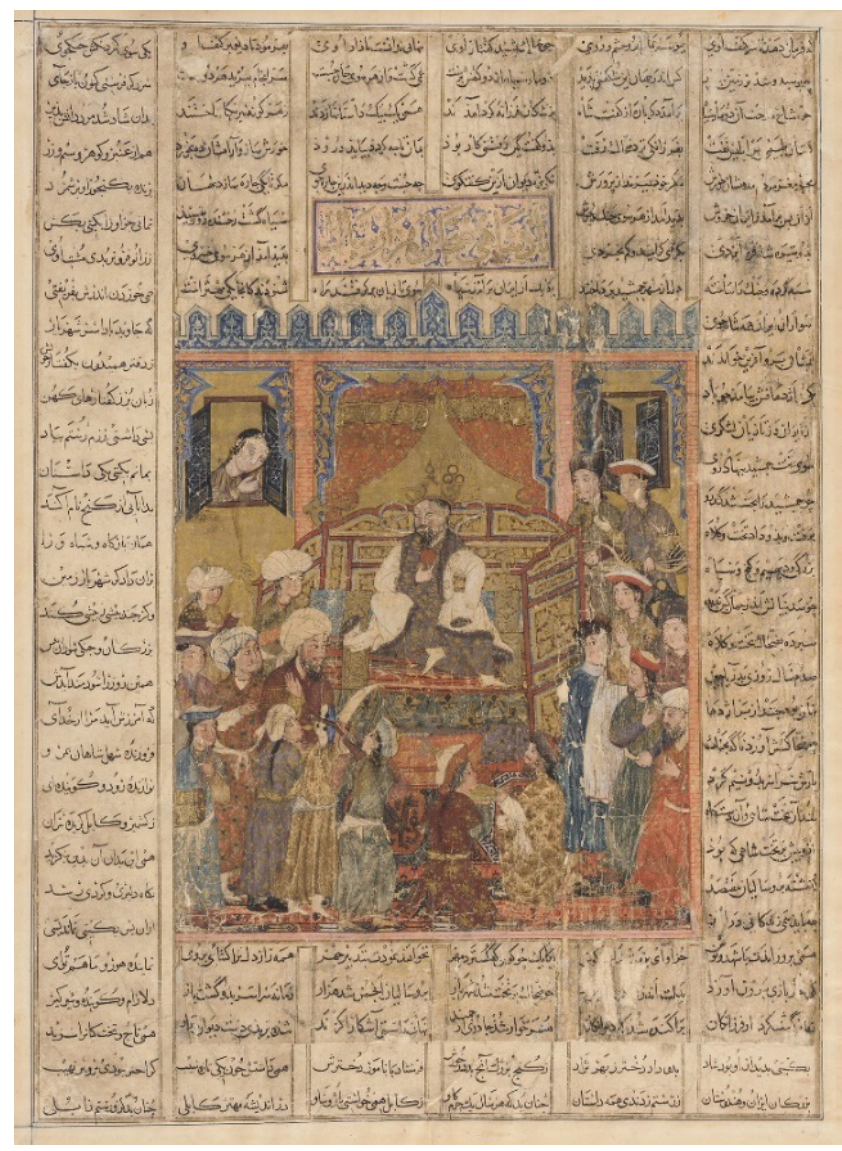

Görsel 20. Demotte Şehnamesi minyatürü. (Warfare,

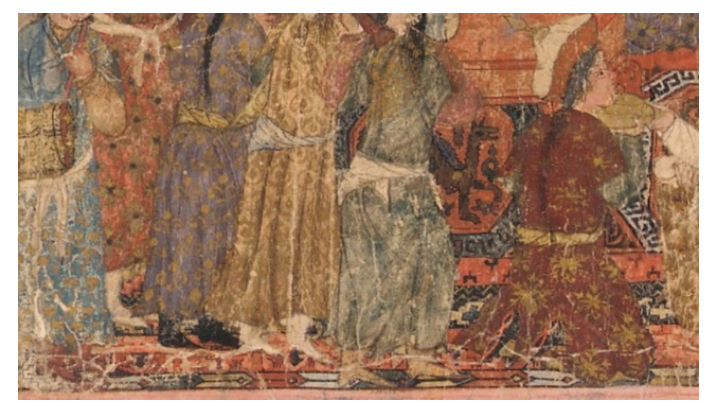

Görsel 21. Demotte Şehnamesi minyatüründe hayvan motifli halının resmedilmesi. (Warfare,

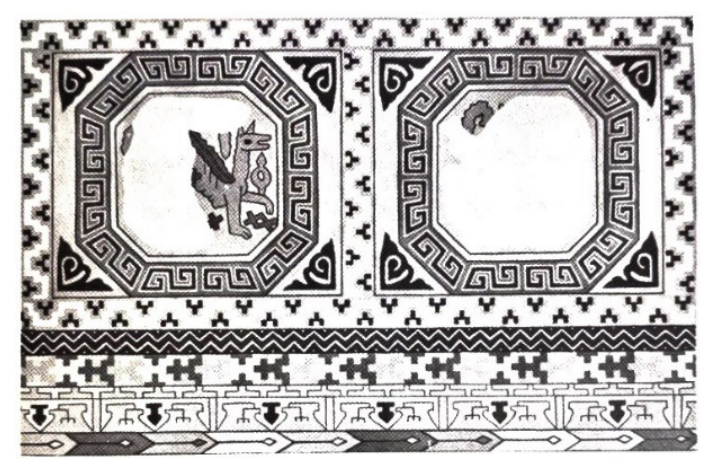

Çizim 6. Demotte Şehnamesi minyatüründe resimlenen hayvan motifli halı çizimi. (Aslanapa ve Durul, 1973, s. 59)

\section{Anka Kuşu}

Anka kuşuna; Anka, Simurg, Zümrüd-ü Anka / Zümrüdü Anka, Phoenix, Tuğrul, Hüma/ Devlet Kuşu, Kara-kuş gibi isimler verilmiştir. Anka kuşunun kökeni Çin'e kadar uzanmaktadır. Anka kuşu, kahramanları koruyucu özelliği ile iyilik, canavar özellikleri ile kötülük sembolü olmuş̧ur. Saltuk-nâme'dęarı Saltuk ile Anka kuşunun karşılaştığı ve Anka kuşunun yavrularının ise Sarı Saltuk'un ölmesini engellediği anlatılmaktadır (Çoruhlu, 2014, s. 29-31). Budist ve Maniheist sanatla bağlantılarında Anka kuşunun, Garuda ve Simurg gibi efsanevi kuşlarla ilişkisi meydana geldiği (Çoruhlu, 2014, s. 23) ve Anka kuşunun tasavvuf ile edebiyatta temsili anlamları vardır.

Anka kuşu; Farsça'da otuz kuş anlamında kullanılan simurg kelimesi ile Özdeştir. Ferîdüddin-i Attar'ın Mantıku'l Tayr adlı eserinde temel konu, Simurg ile aktarılmaktadır. Hikâyeygöre Simurg Allah'ın yarattığı bütün kuşlarısimgelemektedir. Hikâyedđeuşların bunu anlaması, anlayıncaya kadar bazı tasavvufi aşamalardan 


\section{arts $=$}

geçmesi ve tasavvufta Vahdet-i Vücud (varlıkta birlik) düşüncesine dayanarak anlatılmaktadır (Çoruhlu, 1995, s. 23-24; 2014, s. 30-31).

Aydın Uğurlu "bilgiyi Çin'de bile olsa arayın, elde edin" sözüyle bağlantıı olarak Simurg ile ilgili hikayeler içinde en ilginci hakkında "Simurg Çin ülkesinde iken kanadından tüy düşer. Herkes, o tüyden başka çeşit bir nakış, bir resim elde etti. $\bigcirc$ nakışlardan birini gören, bir çeşit iş tuttu, bir çeşit işe girişti. $\bigcirc$ tüy şimdi Çin nigaristanındadır" (1999, s. 56) diye yazarak sanatla ilgisini açıklamıştır.

\section{Çengel}

Çengel pratikte düşünüldüğünde; Anadolu'da kırsal kesimin günlük yaşantısında herkesçe bilinen kuyu çengeli, kasap çengeli, topuzlu kantar çengeli gibi örnekleri ile karşımıza çıkmaktadır. Anadolu insanı çevresinde gördüğü ve kullandığı araç ve gereçleri dokumalarında motif olarak kullanmışlardır.

Çengel motifi Şamanizm kökenli koruyucu semboller arasındadır. Bu motifle ilgili varsayımlardan biri, yin-yang motifinde yin ve yang'ı birbirinden ayıran eğri çizgiyi temsil ettiği düşüncesidir. (Diler ve Gallice, 2018, s. 195). Buna göre yaşamın kaynağı, birleşim ve kavuşmayı ifade etmektedir.

Çengel motifi, Gılgamış Destanı'ndan beri soyut olarak hayat ağacı sembolü olmuştur. Halıda "bitmez tükenmez sonsuz yaşamı simgelemektedir" (Mergen ve Alantar, 2003, s. 88). Çengelli motifler, evren betimlemesi olmaktan çıkmış ve farklı anlam yüklenmiştir (Mergen ve Alantar, 2003, s. 30). Tasarımda ise üst üste sıralanan çengeller, hayat ağacını oluşturmaktadır.

\section{İç İçe Üçgenler}

Üçgen, insanlar için bolluk, bereket, doğurganlık, denge, yükseliş ve sağlamlık gibi kavramlarla bağlantılıdır. Antikçağ'dan beri kullanılan üç ayaklı taşıyıcı tablalardan oluşan "saç ayağı"nın en önemli özelliği "denge"dir. Üçgenin sivri uçlarının farklı yerleştirmeleri ile kadın ve erkeği simgeler. Aşağı ve yukarı bakan üçgenlerin birleşimi ise üçüncü anlam olarak hayat, üreme, çoğalmayı temsil eder. Görsel 16 ve Görsel 17' deki Berlin' deki Ming halısı parçasında Anka kuşu gövdesinde altı köşeli yıldız motifi vardır. Bu motifin kutsallığı, Hz. Süleyman' a kadar uzanmaktadır.

Anadolu'da yörelere göre göz motifi şekilleri değişmekte ve nazar motifi, üçgen, kare, eşkenar dörtgen, dikdörtgen şekillerinde olmaktadır (Ateş, 1996, s. 
156). Şansa ve kötülüğe neden olduğuna inanılan göz motifi ile olumsuz bakışları uzaklaştıran koruyucu nazar motifi, dokumalarda sıklıkla kullanılmıştır.

\section{SONUÇ}

1891 ' deki Viyana' daki Osmanlı Sergisi, Türk halılarının sistematik araştırılmasına veticaretiningelişmesinenedenolmuştur. Viyanasergisini, 1910Münih, 1914Budapeşte sergileri takip etmiştir. Anadolu'da minimalist halde yaşayan Yörük ve Türkmenlerin dokudukları halıların sanatsal özgünlüğü fark eden Batılı araştırmacılar, 19. Yüzyııın son çeyreğinden başlayarak araştırmalarını bu coğrafyaya yönlendirmişlerdir. Bu araştırma ve bilgilere her geçen gün yeni bilgi ve örnekler eklenmektedir.

Araşıırmanın çıkış noktası Ming halısıdır ve 2019 yılından beri bu araştırma üzerinde çalışılmıştır. Bu süreçte, Ming halısı hakkında Türkçe, Almanca, İngilizce basılı ve dijital yazılar ve görseller incelenmiştir. Araştırmalar sırasında yayınlarda bahsedilen iki Ming halısı parçasına ek olarak farklı bir Ming halı parçası olduğu tespit edilmiştir. Bu halı parçasının Berlin'de 1980'li yıllarda saldırıya uğradığı hakkında bir bilgiye ulaşılmışır.

Ming halısının resmeden Domenico di Bartolo ve Bartolomea degli Erri adında ressamların fresk ve tablosu incelenmiştir. Bu iki İtalyan ressamın Ming halısını resimlediği başka resimler olabileceği düşünülmüş, ressamların elektronik ortamda erişilen müze ve özel koleksiyonlardaki tabloları taranmış ve incelenmiştir. Türk halı literatüründe şimdiye kadar bahsedilmemiş Ming halısıyla ilgili Bartolomeo degli Erri ve Agnolo degli Erri kardeşler tarafından yapılan üçüncü tablo bulunmuştur. Araştırma sırasında bu tablo görselinden Kurt Erdmann'ın da 1929 yılında yayımlanmış Jarbuch der Preuszischen Kunstsammlungen adlı müze kitabında, Orientalische Tierteppiche auf Bildern des XIV. und XV. Jahrhunderts başlıklı kitap bölümünde 33 numaralı görselde bahsettiği tespit edilmiş, ancak tablonun künyesinde tablo ve ressam isimlerinin yanlış yazıldığı görülmüştür. Ming halısını tablolarında resmeden ressamların kendilerinin ya da yakın çevrelerinin bir Ming halısına sahip olduğu düşünülmektedir.

Berlin İslam Sanatları Müzesi uzmanlarınca tespit edilen ve Ming halısının sırtında görülen 6 santimetrelik aralıklarla yapılan işaretlemelerin dokumacının günlük çalışmasıyla ilgili bir işaret olduğunu ileri sürmüşlerdir. Anadolu' da nişan adını verdikleri bu işaretlemeler; Ming halısının birden fazla dokumacı tarafından dokunduğunu ve 


\section{$\operatorname{arts}=$}

atölye tipi üretimli halı olduğunu göstermektedir.

\section{KAYNAKÇA}

Aslanapa, O. ve Durul, Y. (1973). Selçuklu Halıları. İstanbul: Akbank.

Aslanapa, O. (1987). Türk Halı Sanatının Bin Yılı. İstanbul: Eren.

Aslanapa, O. (1997) Türk Halı Sanatında Yeni Keşifler. Arış, 1, 10-17.

Aslanapa, O. (2005). Türk Halı Sanatının Bin Yılı One Thousand Years of Turkish Carpets. İstanbul: İnkllap.

Ateş, M. (1996). Mitolojiler Semboller ve Halıar. İstanbul: Symbol.

Beselin, A. (2011). Geknüpfte Kunst Teppiche des Museums für Islamische Kunst. Berlin: Staatliche Museen zu Berlin Museum für Islamiche Kunst.

Beselin, A. (2018). Knots Art \& History The Berlin Carpet Collextion. Milano: Staatliche Museen zu Berlin.

Cahen, C. (1994). Osmanlılardan Önce Anadolu'da Türkler (3. Baskı). İstanbul: e.

Çetintürk, B. (1963). İstanbul'da XVI. Asır Sonuna Kadar Hâssa Halı San'atkârları. İstanbul: Güzel Sanatlar Akademisi Türk San'atı Tarihi Enstitüsü.

Çoruhlu, Y. (1995). Kozmolojik, Mitolojik, Astrolojik, Dini ve Edebi Tasavvurlara Göre Türk Sanatında Hayvan Sembolizmi. İstanbul: Seyran.

Çoruhlu, Y. (2014). Türk Sanatında Hayvan Sembolizmi. İstanbul: Ötüken.

Diler, A. ve Gallice, M. A. (2018). Kilimin Sembolleri (1. Baskı). İstanbul: Alfa.

Eberhard, W. (2000). Çin Simgeler Sözlüğü (Çev. A. Bereket). İstanbul: Kabalcı.

Enderlein, V. (1995). Wilhelm von Bode und die Berliner Teppichsammlung. Berlin: Staatliche Museen zu Berlin.

Erdmann, K. (__ _ Der Türkische Teppich des 15. Jahrhunderts / 15. Asır Türk Halısı. İstanbul: İstanbul Üniversitesi Edebiyat Fakültesi.

Erdmann, K. (1929). Orientalische Tierteppiche auf Bildern des XIV. und $X V$. Jahrhunderts. Jarbuch der Preuszischen Kunstsammlungen (s. 261-298). Berlin: 
Staatliche Museen zu Berlin.

Erdmann, K. (1966). Siebenhundert Jahre Orienteppich. Herford: Bussesche Verlagshandlung GMBH.

Ersan, M. ve Alican, M. (2014). Türklerin Kayıp Yüzyllı Beylikler Devri. İstanbul: Timaş.

Faroqhi, S. (2018). Osmanlılar Kültürel Tarih (Çev. Ç. Sümer). Ankara: Akılçelen.

Flickr. (23 Ağustos 2016) Domenico di Bartolo, Bulunan Çocukların Kabul Edilişi ve Evlendirilişi (1441-1442) freski. Fotoğraf: Raffaele Pagani, Oppadale S. M. Della Scala. flickr.com/photos/94185526@N04/30937074692 Erişim Tarihi: 23 Ağustos 2020

Fondazione Federico Zeri Üniversitesi Fotoğraf Kütüphanesi Kataloğu. catalogo.fondazionezeri.unibo.it/scheda/opera/61665/Erri\%20Agnolo\%20degli\%20 Erri\%20Bartolomeo\%20 degli\%2C\%20Infanzia\%20 di\%20san\%20Tommaso\%20 d\%27Aquino Erişim Tarihi: 10 Mayıs 2020

Franses, M. (2007). Erken Türk Halıarının Kısa Tarihi. A. Karamani Pekin (Ed.), Tanrıya Adanmış Halılar Transilvanya Kiliselerinde Anadolu Halıları 1500-1750 (1. Baskı) (s. 39-50). İstanbul: Kitap.

Hali. (7 Ocak 2019) Berlin İslam Eserleri Müzesi'nde Yeni Halı Galerileri. hali. com/news/new-carpet-galleries-museum-islamic-art-berlin/ Erişim Tarihi: 20 Mayıs 2020

Kröger, J. (2007). Berlin Halı Koleksiyonunun Tarihi. Tanrıya Adanmış Halılar Transilvanya Kiliselerinde Anadolu Halıları 1500-1750 (1. Baskı) (s. 113-127). İstanbul: Kitap.

Kultur Pool. (__ Vincent Ferrer Hayatından Sahne: Deli Annesi Tarafından Parçalanmış ve Kızartılmış Çocuğun Resüsitasyonu. kulturpool.at/plugins/kulturpool/ showitem.action?itemld=270583421313\& Erişim Tarihi: 25 Mayıs 2020

Lamm, C. J. (1985). Carpet Fragments The Marby Rug and Some Fragments of Carpets Found in Egypt. Uddevalla: Nationalmuseum.

Mack, R. E. (2005). Doğu Malı-Batı Sanatı (Çev. A. Özdamar). İstanbul: Kitap. Marketplace News (1992, August). Hali, 64, 162-163.

Mergen, S. ve Alantar, H. (2003). Tarihi Anadolu Halıları Bant 1. İstanbul: Sentez 


\section{$\operatorname{arts}=$}

Turizm.

Mills, J. (1994). Love and Understanding A Personal Choice from the Orient Stars Collection. Carpet\&Textile Art The 1994 Halı Annual (s. 24-33). London: Hali Publications.

Ölçer, N. (1997). 13.-18. yüzyıl Türk Halıları Sergisi. Arış, 1, 16-23.

Rugkazbah. (_) Kirchheim koleksiyonundaki hayvan motifli halı ve halı parçaları. rugkazbah.com/boards/records.php?id=2426\&refnum=2426 Erişim Tarihi: 02 Ocak 2021

Rugtracker. (27 Ocak 2021) Basel Wölkerkunde Museum'da bulunan Ming halısı parçası. Kahire antika pazarı bulunan kufi yazı benzeri bordürlü Ming halı parçası. Berlin'de bulunan ve 1980'li yıllarda saldırıya uğrayan Ming halısı parçası. rugtracker.com/2021/01/ Erişim Tarihi: 06 Haziran 2021

Schmidt, H. (1958). Alte Seiden Stoffe. Braunschweig: Klinkhardt\&Biermann.

The National Gallery. (__ Niccolò di Buonaccorso'nun "Meryem'in Evlenmesi" (1380), National Gallery, Londra. nationalgallery.org.uk/paintings/ niccolo-di-buonaccorso-the-marriage-of-the-virgin Erişim Tarihi: 07 Haziran 2021

Uğurlu, A. (1999). Türk Sanatında Masal Varlıkları. Ev Tekstili, 21, 56-60.

Uzunçarşlı, I. H. (1988). Anadolu Beylikleri ve Akkoyunlu, Karakoyunlu Devletleri (4. Baskı). Ankara: Atatürk Kültür, Dil ve Tarih Yüksek Kurumu.

Warfare. (__ Demotte Şehnamesi minyatürü. warfare.tk/Persia/14/Great_ Mongol_Shahnama-The_Iranians_place_Zahhak_on_the_

throne-Freer_F1923_5-Ig.htm Erişim Tarihi: 17 Haziran 2020

Werner, E. (2014). Büyük Bir Devletin Doğuşu: Osmanlılar (1300-1481) Osmanlı Feodalizminin Oluşum Süreci (Çev. O. Esen ve Y. Öner). İstanbul: Yordam Kitap.

Wikiwand. (__ Bartolomeo degli Erri. wikiwand.com/it/Bartolomeo_degli_ Erri Erişim Tarihi: 15 Haziran 2020

Wikimedia Commons. (18 Şubat 2018) Bartolomeo degli Erri - Aziz Thomas Aquina'nın Doğuşu - 1871.41 - Yale Üniversitesi Sanat Galerisi. commons. wikimedia.org/wiki/File:Bartolomeo_degli_Erri_The_Birth_of_Saint_Thomas_ Aquina_-_1871.41_-_Yale_University_Art_Gallery.jpg Erişim Tarihi: 18 Haziran 2020 